\title{
Retained particle surface area dose drives inflammation in rat lungs following acute, subacute, and subchronic inhalation of nanomaterials
}

Frédéric Cosnier ${ }^{1 *}$ D, Carole Seidel ${ }^{1}$, Sarah Valentino ${ }^{1}$, Otmar Schmid ${ }^{2,3}$, Sébastien Bau ${ }^{1}$, Ulla Vogel $^{4,5}$, Jérôme Devoy ${ }^{1}$ and Laurent Gaté ${ }^{1}$

\begin{abstract}
Background: An important aspect of nanomaterial (NM) risk assessment is establishing relationships between physicochemical properties and key events governing the toxicological pathway leading to adverse outcomes. The difficulty of NM grouping can be simplified if the most toxicologically relevant dose metric is used to assess the toxicological dose-response.

Here, we thoroughly investigated the relationship between acute and chronic inflammation (based on polymorphonuclear neutrophil influx (\% PMN) in lung bronchoalveolar lavage) and the retained surface area in the lung. Inhalation studies were performed in rats with three classes of NMs: titanium dioxides $\left(\mathrm{TiO}_{2}\right)$ and carbon blacks (CB) as poorly soluble particles of low toxicity (PSLT), and multiwall carbon nanotubes (MWCNTs). We compared our results to published data from nearly 30 rigorously selected articles.

Results: This analysis combined data specially generated for this work on three benchmark materials $-\mathrm{TiO}_{2} \mathrm{P} 25$, the CB Printex-90 and the MWCNT MWNT-7 - following subacute (4-week) inhalation with published data relating to acute (1-week) to subchronic (13-week) inhalation exposure to the classes of NMs considered. Short and long postexposure recovery times (immediately after exposure up to more than 6 months) allowed us to examine both acute and chronic inflammation.

A dose-response relationship across short-term and long-term studies was revealed linking pulmonary retained surface area dose (measured or estimated) and \% PMN. This relationship takes the form of sigmoid curves, and is independent of the post-exposure time. Curve fitting equations depended on the class of NM considered, and sometimes on the duration of exposure. Based on retained surface area, long and thick MWCNTs (few hundred nm long with an aspect ratio greater than 25) had a higher inflammatory potency with $5 \mathrm{~cm}^{2} / \mathrm{g}$ lung sufficient to trigger an inflammatory response (at $6 \% \mathrm{PMN}$ ), whereas retained surfaces greater than $150 \mathrm{~cm}^{2} / \mathrm{g}$ lung were required for PSLT.
\end{abstract}

\footnotetext{
* Correspondence: frederic.cosnier@inrs.fr

'Institut National de Recherche et de Sécurité, 1 Rue du Morvan, CS 60027, 54519 Vandœuvre-les-Nancy Cedex, France

Full list of author information is available at the end of the article
}

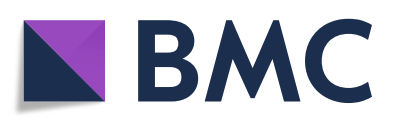

(- The Author(s). 2021 Open Access This article is licensed under a Creative Commons Attribution 4.0 International License, which permits use, sharing, adaptation, distribution and reproduction in any medium or format, as long as you give appropriate credit to the original author(s) and the source, provide a link to the Creative Commons licence, and indicate if changes were made. The images or other third party material in this article are included in the article's Creative Commons licence, unless indicated otherwise in a credit line to the material. If material is not included in the article's Creative Commons licence and your intended use is not permitted by statutory regulation or exceeds the permitted use, you will need to obtain permission directly from the copyright holder. To view a copy of this licence, visit http://creativecommons.org/licenses/by/4.0/. The Creative Commons Public Domain Dedication waiver (http://creativecommons.org/publicdomain/zero/1.0/) applies to the data made available in this article, unless otherwise stated in a credit line to the data. 
Conclusions: Retained surface area is a useful metric for hazard grouping purposes. This metric would apply to both micrometric and nanometric materials, and could obviate the need for direct measurement in the lung. Indeed, it could alternatively be estimated from dosimetry models using the aerosol parameters (rigorously determined following a well-defined aerosol characterization strategy).

Keywords: Inhalation, Aerosol, Rat, Titanium dioxide, Carbon black, Multiwall carbon nanotube, SBET, Neutrophil influx, Retained surface area, MPPD

\section{Background}

Exposure to particles is an issue in everyday life and occupational health. Indeed, inhalation of particles and in particular of nanomaterials (NMs) may induce many pulmonary adverse outcomes (AO) [1].

The recently completed EU-funded Smartnanotox project (www.smartnanotox.eu) leveraged data from in vivo, in vitro and in silico studies, and proposed pulmonary AO pathways (AOPs) for inhaled NMs, presenting their associated molecular initiating events or key events (KEs). This structured AOP-based approach for hazard grouping is now considered a relevant tool to assess the risks associated with inhaled materials, particularly for NMs $[1,2]$.

Both inflammation and oxidative stress are central mechanisms driving NM-induced adverse effects [3]. The extent of pulmonary inflammation depends on the amount of inhaled NM deposited in the lung, in particular in deep lung (i.e., the alveolar region), since mucociliary particle clearance rapidly and effectively clears the upper airways of deposited particles [4]. Particles deposited in the lung remain either for only a short duration (acute), as they are gradually eliminated over time due to various clearance mechanisms, or persist long-term, in which case they can induce chronic inflammation leading to pathologies such as chronic obstructive pulmonary disease (COPD), emphysema, lung fibrosis, or cancer $[5,6]$.

One hallmark or KE of the inflammatory response in the lungs is the increased recruitment of circulating inflammatory cells $[7,8]$. The influx of inflammatory leukocytes, especially polymorphonuclear neutrophils (PMN) which play a major role in the pathogenesis of many respiratory diseases [9], can be assessed using bronchoalveolar lavage (BAL). This method involves rinsing the epithelial surface of the lung with saline solution, the number of PMNs present in the recovered fluid (BALF) can then be counted [10].

As part of a drive to standardize risk assessment or predict risks association with new NMs, research seeks to establish relationships between the physicochemical properties of NMs and the KEs triggering the toxicity pathway leading to AO. Based on these relationships, descriptors can be identified to group NMs according to their toxicological mode-of-action. The difficult task of NM grouping can be substantially simplified if the most toxicologically relevant dose metric is used to measure the toxicological dose-response $[11,12]$.

In the past decade, growing evidence suggests that deposited or retained particle (NM) surface area normalized to lung mass can be leveraged to unify in vivo inflammation data from mice and rats, based on PMN numbers normalized to total cell numbers in the BALF, and to identify distinct classes of NM. Representatives of some of the different NM classes include titanium dioxide $\left(\mathrm{TiO}_{2}\right)$ [12, 13], multiwall carbon nanotubes (MWCNTs) [14-16], nano-ceria [17], granular biodurable particles and transition metal oxides [12, 18-20], diesel exhaust particles [21], nanoclays [22], and halloysite nanotubes [23].

In the present study, we thoroughly investigated the relationship between inflammation and the lung retained surface area dose for three classes of $\mathrm{NMs}-\mathrm{TiO}_{2}$, carbon blacks (CBs) and MWCNTs - following inhalation in rats. $\mathrm{TiO}_{2}$ and $\mathrm{CBs}$ are generally considered granular PSLT (Poorly Soluble particles of Low Toxicity) [12, 24], whereas MWCNTs are high aspect ratio nanomaterials (HARN).

Data specifically generated for 4-week exposure to three benchmark materials $\left(\mathrm{TiO}_{2} \mathrm{P} 25, \mathrm{CB}\right.$ Printex-90, and MWCNT MWNT-7 (Mitsui-7)) were combined with data from nearly 30 published studies covering a range of exposure durations (1 week to 13 weeks) and post-exposure recovery times (from immediately after exposure up to more than 6 months) to elucidate the effects of dose and dose rate on both acute and chronic lung inflammation.

\section{Materials \& methods}

Analysis combined both newly-acquired data from our laboratory using three benchmark materials administered by subacute (4-week) nose-only (NO) inhalation the protocol for which is detailed in paragraphs 2.1 to 2.4 - with data from 27 rigorously selected articles reporting acute (1-week) to subchronic (13-week) inhalation of the classes of NMs considered - these studies are detailed in paragraph 2.5 .

\section{Materials \& characteristics}

The three benchmark materials - $\mathrm{TiO}_{2} \mathrm{P} 25$, the $\mathrm{CB}$ Printex-90 and the MWCNT MWNT-7 (Mitsui-7) - are 
representatives of the three classes of NMs. These materials were selected as there is abundant literature data related to them. All three are classified in group 2B ("possibly carcinogenic to humans") by the International Agency for Research on Cancer [25, 26], and induce lung cancer following chronic inhalation in rats [27, 28].

$\mathrm{TiO}_{2}$ P25 (Aeroxide ${ }^{\bullet}$ P25) was purchased from Evonik. It is a pure $\left(99.9 \% \mathrm{TiO}_{2}\right)$ mixed-phase nanocrystalline powder composed of $87 \%$ anatase and $13 \%$ rutile crystallites, with average primary particle diameters of $21 \pm 1.5$ $\mathrm{nm}$ and $40 \pm 1.5 \mathrm{~nm}$, respectively [29]. Printex 90 (a furnace carbon black from Evonik) and MWNT-7 (Mitsui7 MWCNT supplied by Mitsui Company) were kindly donated by Mitsui Company via the National Research Centre for the Working Environment (Copenhagen, Denmark). Average particle size of Printex-90 is $14 \mathrm{~nm}$, with purity of around $99 \%$ carbon. MWNT-7 is a long $(5.0 \pm 4.5 \mu \mathrm{m})$ and thick (diameter $=88 \pm 5 \mathrm{~nm}) \mathrm{MWCNT}$ composed of $99 \%$ carbon.

Gas $\left(\mathrm{N}_{2}\right)$ adsorption measurements performed on the batches of P25, Printex-90, and MWNT-7 used in this study yielded specific surface areas of 55, 316 and 15 $\mathrm{m}^{2} / \mathrm{g}$, respectively, according to the BET model. Since these materials are not micro or mesoporous, these surface areas correspond to the outer surface of the particles.

\section{Animal care and exposure}

Animal experiments were performed in accordance with European Union Directive 2010/63/EU and with French regulations related to the protection of animals used for scientific purposes, and were conducted in a laboratory animal facility accredited by the French Ministry of Agriculture (Accreditation No D54-547-10). Experimental procedures were approved by the local Ethics Committee and registered by the French Ministry for Research and Higher Education (Authorization n00692.01 \& APAFIS\#10052).

Ten-week-old female Sprague-Dawley rats were purchased from Janvier Labs (Le Genest Saint Isle, France). Rats were housed in individually ventilated cages (GR900, Tecniplast) maintained in $12 \mathrm{~h} / 12 \mathrm{~h}$ light/dark cycles, and when not in restraining tubes had ad libitum access to food (A04 Safe diet) and water. Two weeks before nose-only exposure to NM aerosols, rats were gradually acclimatized to the restraining tubes.

Animals (from 13 weeks old; 6 rats per group) were then nose-only exposed to either filtered air or NM aerosols (conditioned at $22 \pm 2{ }^{\circ} \mathrm{C}$ and a relative humidity of $55 \pm 10 \%$, in line with the OECD TG 412 guideline [30]) for $6 \mathrm{~h} /$ day, 5 days/week for 4 weeks. At least three dose groups were tested for each NM. High dose groups were exposed daily for $6 \mathrm{~h}$ to the target concentration: 15,50 , and $1.5 \mathrm{mg} / \mathrm{m}^{3}$ for P25, Printex-90, and MWNT-7, respectively. Based on the Concentration $\times$ Time $(C \times t)$ protocol [31], assuming a similar time-dependent lung deposition of the nanostructured aerosols, the medium and low dose groups (expressed as 6 h-equivalent concentrations) were created by modulating the time that animals were exposed to aerosols and assuming a similar time-dependent lung deposition. Exposure to 5 and 15 $\mathrm{mg} / \mathrm{m}^{3}$ Printex-90 and 0.5 and $0.15 \mathrm{mg} / \mathrm{m}^{3}$ MWNT-7 was achieved by exposing rats for 120 and $36 \mathrm{~min}$ daily to the target aerosol concentrations $\left(50\right.$ and $1.5 \mathrm{mg} / \mathrm{m}^{3}$, respectively).

To investigate acute effects of $\mathrm{TiO}_{2}$, in addition to the 5 and $1.5 \mathrm{mg} / \mathrm{m}^{3}$ groups, three additional groups (10 rats per group) were exposed for 2 weeks to the same concentration levels (or $6 \mathrm{~h}$-equivalent levels): 15, 5, and 1.5 $\mathrm{mg} / \mathrm{m}^{3}$.

Finally, to observe any effects due to differences in agglomeration states in $\mathrm{TiO}_{2}$ aerosols produced from the same starting material, we exposed 13-week-old male Fisher F344 rats (Charles River Laboratories, France) to a $5 \mathrm{mg} / \mathrm{m}^{3}$ suspension of $\mathrm{TiO}_{2} \mathrm{P} 25$ for $6 \mathrm{~h} /$ day, 5 days/ week for 4 weeks.

Respiratory parameters of control and exposed rats were monitored using plethysmography systems (from Electro-Medical Measurement Systems, Bordon, UK) before, during and after the inhalation exposures. The animals were inside head-out plethysmographs (put directly on the inhalation towers) to measure (once a week) the thoracic flow during exposure and to access the following parameters: tidal volume, inspiration and expiration times, peak inspiratory and expiratory flows, breathing frequency, minute volume and end inspiratory and expiratory pauses. In addition, double-chamber plethysmographs were used the week preceding the exposures or the day preceding the necropsy of the animals to measure nasal and thoracic flows allowing evaluation of the Specific Airway Resistance.

$\mathrm{TiO}_{2}$ aerosols were produced from powder using a rotating brush aerosol generator (RBG1000, PALAS, Karlsruhe, Germany) [32] or from a suspension $(100 \mathrm{mg} / \mathrm{L})$ in ultrapure water using two nebulizers operated in parallel (AGK2000, PALAS, Karlsruhe, Germany). Printex-90 aerosol was generated using an SAG410/U solid aerosol generator (TOPAS, Dresden, Germany); and MWNT-7 aerosol was produced by an upgraded (high-pressure version) of an acoustic generator (IEStechno, Morgantown, USA) [14, 33] (Supplemental 1 and 2).

Details of the inhalation exposure set-up and the strategy used to characterize and monitor aerosols have been previously described [32]. Briefly, aerosol monitoring relied on the use of (1) a condensation particle counter (CPC) (TSI, model 3007, Shoreview, Minnesota, USA) for the on-line measurement of total submicron particle concentrations, (2) an optical particle counter (OPC) 
(FIDAS mobile, PALAS, Karlsruhe, Germany) to monitor the airborne particle number size distribution, and (3) systematic closed-face cassette samplers (CFC equipped with PVC or PTFE membranes filters, Millipore, Molsheim France) changed two to four times per day to measure the average mass concentration of the aerosol by gravimetry (XP6U, Mettler-Toledo, Viroflay, France - $0.1 \mu \mathrm{g}$ resolution). The in-depth characterization of relevant aerosol parameters is described in the same reference [32]. Briefly, it was achieved using time-resolved instruments such as scanning mobility particle sizer (SMPS) (Differential Mobility Analyzer TSI 3082 + Water-based CPC TSI 3787, Shoreview, Minnesota, USA), aerodynamic particle sizer (APS) (TSI 3321, Shoreview, Minnesota, USA), or electrical low-pressure impactor (ELPI, Dekati, Finland). The need for multiple direct-reading instruments is due to the wide range of particle diameters to be covered, typically from $10 \mathrm{~nm}$ to $20 \mu \mathrm{m}$. The size range covered by each instrument should be addressed during experiment design to ensure appropriate ranges are included. This adaptation is particularly important when further data merging is applied to yield a continuous distribution over the whole range. Time integrated sampling (using SIOUTAS or DLPI+ cascade impactors for example) for a posteriori aerosol characterization is also very important, not only to characterize the aerosols produced in accordance with standard ISO 13014 [34], but also to leverage standard computational lung dosimetry models to estimate the particle dose retained.

\section{Necropsy, tissue sampling}

Lung samples were collected from animals 3,30 or 180 days (D3, W4 and W26) after the end of the inhalation exposure. Two additional post-exposure times, D0 and W13 (immediately following the last day of exposure, and 90 days later), were also considered with nebulized P25 inhalation exposure to allow comparison with data previously published by our group relating to agglomerated P25 [35, 36]. Animals were anesthetized by intraperitoneal injection of a mixture of xylazine $(10 \mathrm{mg} / \mathrm{kg}$ body weight) and ketamine ( $75 \mathrm{mg} / \mathrm{kg}$ body weight), then euthanized by exsanguination through the abdominal aorta. After ligation, lung tissue was collected, sectioned, weighed; some lobes were snap frozen in liquid nitrogen and stored at $-80^{\circ} \mathrm{C}$ until further analysis.

\section{Analysis of bronchoalveolar lavage fluid (BALF) and NM lung burden}

Following inhalation exposure, deposition is assumed to be homogeneous throughout the lung (no difference between lobes) [37]. BAL was performed on the left lung as described in [14,35]. Left lungs were flushed 5 times with $4 \mathrm{~mL}$ of ice-cold PBS and the pooled BAL fluids were centrifuged $5 \mathrm{~min}$ at $4{ }^{\circ} \mathrm{C}$ at $400 \mathrm{~g}$. Cells from cell pellets were counted using acridine orange - propidium iodide with the Cellometer ${ }^{\mathrm{m}}$ (Nexcelom) and MayGrünwald-Giemsa staining was performed on cytospin slides. Macrophages, PMN and lymphocytes were counted (500 cells/animal) and the \%PMN was calculated from the ratio of neutrophils to total cells in BALF. The right median lobe was frozen and used to quantify the NM lung burden.

The $\mathrm{TiO}_{2}$ lung burden was determined from elemental $\mathrm{Ti}$ analysis by ICP-MS, as previously described [36, 38] The MWCNT and CB lung burdens (for Printex-90 samples or samples containing short and thin MWCNTs) were quantified by thermogravimetric analysis (TGA) of lyophilized samples after chemical digestion of the tissues with a water-based tissue solubilizer (Solvable, Perkin-Elmer) [39]. The NM surface area retained (in $\mathrm{cm}^{2} / \mathrm{g}$ lung) was calculated for each rat from the retained mass and the wet lung weight (in $\mathrm{mg} / \mathrm{g}$ lung) combined with the mass-specific BET surface area determined for each material.

\section{Selection of published studies}

In addition to the nose-only inhalation studies described above, more than 50 studies (published before May 2020) relating to pulmonary toxicity of $\mathrm{TiO}_{2}, \mathrm{CB}$ and/or MWCNT after inhalation exposure and using rat as animal model were screened; 27 of them were selected based on the following criteria:

i) Exposure was by whole-body (WB), head-only $(\mathrm{HO})$ or nose-only $(\mathrm{NO})$ inhalation.

ii) Exposure was acute (few days), subacute (4 weeks), or subchronic (13 weeks). Studies describing chronic exposure (2 years) were omitted to avoid the emergence of biological regulation mechanisms specific to long-term exposures.

iii) Results included data on \% PMN (polymorphonuclear cells) or PMN and total cell number in the BALF for at least one post-exposure time.

iv) Lung burden (retained mass dose and lung mass) and how it was measured was reported.

Alternatively, accurate information was provided (or available) on the aerosol characteristics (Count Median Diameter (CMD), Mass Median Aerodynamic Diameter (MMAD) and corresponding Geometric Standard Deviation (GSD), actual mass concentration, etc.) as well as animal strain, sex and biometry (at least body and lung weight) to allow calculation of the retained mass using the Multiple-Path Particle Model (MPPD) dosimetry model (cf. $\$ 2.6$ ). 
v) Accurate physicochemical information was available on the powder used: diameter (and length) of primary particles (tube), chemical purity, crystallographic form if applicable, and most importantly mass-specific BET surface area for conversion of the pulmonary NM mass dose into a surface area dose.

\section{Estimating pulmonary retention}

Pulmonary deposition and retention after inhalation were estimated using the MPPD model (v.3.04), applying the asymmetric Sprague-Dawley airway morphometry $[40,41]$ and the clearance mode (https://www.ara.com/ products/multiple-path-particle-dosimetry-model-mppd$\mathrm{v}$-304). The physiological parameters used were functional residual capacity (FRC), upper respiratory tract volume (URT), tidal volume, breathing frequency. For all these parameters, the default MPPD values for a given rat weight (which may differ from one study to another) were taken [42]. Specific exposure (and post-exposure) times were entered, whereas default rat clearance settings were used to estimate retention (mainly alveolar).

MMAD and its associated GSD were considered more relevant than CMD for mass-based dosimetry calculations [43].

When estimating fractions of MWCNT deposited (and especially the pulmonary fraction for this study), aspect ratio values are very important. However, these values are difficult to determine since they depend on the tendency of the MWCNTs to form agglomerates [14, 44]. For 'fibre-like' MWCNT such as MWNT-7 [45], the mean aspect ratio of individual fibres was used for MPPD modelling. However, for more entangled and 'broadly-spherical' MWCNT aerosols, the mean aspect ratios of the aerosols (estimated from transmission electron microscopy images of the aerosols collected on grids) rather than that of the original CNTs was used for dosimetry modelling (for NM403, Baytubes or Graphistrength for example) [14, 46, 47]. For aerosols containing both isolated CNTs and relatively spherical agglomerates (the case of NM401), an average value (=30 for NM401) between the aspect ratio of the original CNTs $(=4 /$ $0.067=60)$ and that of a spherical particle $(=1)$ was taken as default [14]. Any interpretation of the data relying on modelled retained doses must be considered with the significant uncertainties resulting from these choices in mind.

\section{Model fitting}

Whole data given in the tables are expressed as the mean \pm standard deviation. Dose-response curves (\%neutrophils as a function of retained NM surface area per lung weight) were fitted to a sigmoidal curve, based on average values rather than individual animal data using the Hill equation (general equation for a sigmoidal doseresponse curve) with the following form [48]:

$$
\begin{aligned}
& \% \text { neutrophils }=\% \text { neutro }_{\text {in }} \text { controls } \\
& +\frac{\%_{\text {neutro }} \text { max }_{\text {nentro }}-\% \text { in controls }}{1+\left(\frac{E C 50}{\text { deposited surface area }}\right)^{\text {Hill slope }}}
\end{aligned}
$$

where:

- \%neutro in controls $(=1.8 \%)$ corresponds to the average basal \%neutrophils (endogenous) measured in all the (air exposed) control groups regardless of post-exposure time and rat strain, in this work and in previous studies from our laboratory [14, 35],

- \%neutro $\max _{\text {ax }}$ is the asymptotic maximum response observed only for high enough NM doses (typically between 70 and 80\%); by default, this value was set to $75 \%$ for modelling,

- EC50 is the retained surface area dose (per lung weight) that provokes a response halfway between baseline (\%neutro in controls) and the asymptotic high maximum response (\%neutro max),

- Hill slope quantifies the steepness of the doseresponse curve at EC50.

Both EC50 and Hill slope were determined by fitting a curve to the specific dataset under consideration using Statgraphics Centurion XVIII Software (Version 18.1.06) (StatPoint Technologies, Inc., Warrenton, VA, USA). The 95\% confidence limits were established from the asymptotic standard errors.

\section{Results}

\section{Aerosol monitoring and characterization}

Table 1 summarizes the target and actual mass concentrations delivered as well as the main characteristics of the three benchmark NM aerosols: number concentration, count modal aerodynamic diameter (CMoAD) and associated GSD, MMAD, and aerosol effective density (average aerosol mass per volume based on mobility diameter [49]). Representative transmission electron microscopy images of the aerosols and their corresponding particle number (or mass) size distributions are provided in Supplemental 3 and 4, respectively.

The mean actual NM aerosol concentrations never deviated by more than $13 \%$ from the target concentrations; with most deviations at less than $3 \%$. As specified in the OECD TG 412 guideline [30], the test substance concentration sampled in the animals' breathing zone in an inhalation chamber should not deviate from the mean chamber concentration by more than $\pm 20 \%$ for solid aerosols. Variations of 25 to $30 \%$ were observed under certain conditions, when the generation capacities were 
Table 1 Main characteristics of $\mathrm{TiO}_{2}$ P25, Printex-90, and MWNT-7 aerosols produced for inhalation studies

\begin{tabular}{|c|c|c|c|c|c|c|c|}
\hline Material & $\begin{array}{l}\text { Target concentration } \\
\left(\mathrm{mg} / \mathrm{m}^{3}\right)\end{array}$ & $\begin{array}{l}\text { Actual concentration } \\
\left(\mathrm{mg} / \mathrm{m}^{3}\right)\end{array}$ & $\begin{array}{l}\text { Number concentration } \\
\left(\text { particle } \times 10^{4} / \mathrm{cm}^{3}\right)\end{array}$ & $\begin{array}{l}\text { MMADd } \\
(\mu \mathrm{m})\end{array}$ & $\begin{array}{l}\text { CMoAD } \\
(\mu \mathrm{m})\end{array}$ & GSD $^{e}$ & $\begin{array}{l}\text { Aerosol effective density } \\
\left(\mathrm{g} / \mathrm{cm}^{3}\right)^{\mathrm{f}}\end{array}$ \\
\hline P25 & $\begin{array}{l}15 \\
15 \text { (2-week) } \\
5^{\mathrm{a}} \\
5^{\mathrm{a}} \text { (2-week) } \\
1.5^{\mathrm{a}} \\
1.5^{\mathrm{a}} \text { (2-week) }\end{array}$ & $\begin{array}{l}15.3 \pm 3.98 \\
15.3 \pm 3.54 \\
5.02 \pm 0.39 \\
5.04 \pm 1.30 \\
1.59 \pm 0.45 \\
2.20 \pm 0.64\end{array}$ & $5.1 \pm 1.7$ & 1.56 & 0.31 & 1.72 & 1.70 \\
\hline P25 & $5^{b}$ & $5.09 \pm 0.65$ & $27 \pm 2$ & 0.40 & 0.17 & 1.82 & 0.90 \\
\hline Printex-90 & $\begin{array}{l}50 \\
15^{a} \\
5^{a}\end{array}$ & $\begin{array}{l}50.1 \pm 3.89 \\
15.0 \pm 1.24 \\
4.89 \pm 0.39\end{array}$ & $35 \pm 14$ & 0.94 & $\begin{array}{l}0.03 \\
\& 0.20\end{array}$ & $\begin{array}{l}1.97 \\
\& 2.11\end{array}$ & 0.35 \\
\hline MWNT-7 & $\begin{array}{l}1.5 \\
0.5^{\mathrm{a}} \\
0.15^{\mathrm{a}}\end{array}$ & $\begin{array}{l}1.69 \pm 0.49 \\
0.47 \pm 0.15 \\
0.13 \pm 0.02\end{array}$ & $0.14 \pm 0.05$ & 1.78 & 0.40 & 1.69 & 0.45 \\
\hline
\end{tabular}

\footnotetext{
${ }^{a} 6$ h-equivalent concentration created by modulating the time for which animals were exposed to the aerosols produced from a dry powder generator baerosol produced from a nebulized suspension

${ }^{c}$ Measured by CPC particle diameter $\mathrm{d}_{\mathrm{p}}<3 \mu \mathrm{m}$

${ }^{\mathrm{d} D e t e r m i n e d ~ f r o m ~ c a s c a d e ~ i m p a c t o r ~(D P L I+) ~ s a m p l i n g, ~ s u b s e q u e n t ~ g r a v i m e t r i c ~ a n a l y s i s ~ a n d ~ f u r t h e r ~ d a t a ~ i n v e r s i o n ~ t o ~ a c c o u n t ~ f o r ~ p a r t i c l e ~ d e p o s i t i o n ~}$ probabilities [50]

e Determined from a log-normal fitting of the number size distribution provided either by SMPS or APS measurements

${ }^{f}$ Aerosol effective densities were estimated by merging SMPS and APS number size distributions and assuming spherical particles [51]. These data shall be considered as indicative values
}

pushed to the limits [P25 by rotating brush generator (RBG) at $15 \mathrm{mg} / \mathrm{m}^{3}$ or MWNT-7 by acoustic generator at $\left.1.5 \mathrm{mg} / \mathrm{m}^{3}\right]$. To ensure sufficient exposure of the lower respiratory tract (alveolar region) in rats, the aerosols met the following standard: MMAD $\leq 2 \mu \mathrm{m}$ with GSD between 1 and 3 .

Despite similar CMoAD (0.17 instead of $0.31 \mu \mathrm{m})$, $\mathrm{TiO}_{2}$ aerosols produced by nebulization had a 4-fold smaller MMAD $(0.4 \mu \mathrm{m})$ than when produced by RBG $(1.56 \mu \mathrm{m})$ (Supplemental 4). When normalized to mass concentration, the number concentration for the aerosol produced by nebulization was around 16-fold higher $\left(5.4 \times 10^{4}\right.$ particles $/ \mathrm{cm}^{3}$ per $\left.\mathrm{mg} / \mathrm{m}^{3}\right)$ than that obtained with a RBG $\left(3.4 \times 10^{3}\right.$ particles $/ \mathrm{cm}^{3}$ per $\left.\mathrm{mg} / \mathrm{m}^{3}\right)$. The particle size distribution in number for the Printex-90 aerosol was bimodal (CMoADs of 0.03 and $0.2 \mu \mathrm{m}$ ), its total mass-normalized number concentration $\left(7.0 \times 10^{3}\right.$ particles $/ \mathrm{cm}^{3}$ per $\mathrm{mg} / \mathrm{m}^{3}$ ) was of the same order of magnitude ( 2-fold higher) as that of $\mathrm{TiO}_{2} \mathrm{RBG}$ aerosol, but nearly 8 -fold higher than that for MWNT-7 $\left(9 \times 10^{2}\right.$ particles $/ \mathrm{cm}^{3}$ per $\mathrm{mg} / \mathrm{m}^{3}$ ).

\section{Lung burden \& neutrophil influx following exposure to the three benchmark NMs}

As expected, exposure to increasing aerosol concentrations induced increasing lung burdens (deposition). Over time, a fraction of the deposited particles was cleared from the lung and the amount retained decreased (Table 2). Details of the cytology results as well as body and lung weights are available in Supplemental 5.

Following exposure to P25 agglomerated aerosols generated from dry powder, the amount of $\mathrm{TiO}_{2}$ retained within the lung (normalized to the P25 airborne concentration in $\mathrm{mg} / \mathrm{m}^{3}$ ) was around $274 \mu \mathrm{g} / \mathrm{g}$ lung (per $\mathrm{mg} / \mathrm{m}^{3}$ ) (Supplemental 6). This was $25 \%$ higher than the amount of aerosol (less agglomerated) retained following exposure to the nebulized P25 aqueous suspension $\left(221 \mu \mathrm{g} / \mathrm{g}\right.$ lung per $\left.\mathrm{mg} / \mathrm{m}^{3}\right)$. Considering the actual respiratory parameters of rats (i.e., tidal volume, breathing frequency and minute ventilation measured by thoracic plethysmography during exposure), the fractions retained were quite similar: 13.3 and $15.1 \%$ of the P25 aerosol dose was inhaled. The fractions retained (sum of pulmonary and tracheobronchial fractions) were somewhat higher than those estimated by the MPPD model: 8.2 and $10.1 \%$, respectively. Using first order kinetic models, an elimination half-time of 52 days was estimated for the nebulized $\left(5 \mathrm{mg} / \mathrm{m}^{3}\right)$ P25 aerosol, whereas it was 70 days for the $1.5 \mathrm{mg} / \mathrm{m}^{3}$ and exceeded 98 days for the 5 and $15 \mathrm{mg} / \mathrm{m}^{3}$ (dry) aerosols (Supplemental 6).

Printex-90 exposures did not deliver the same normalized deposited dose (normalized to Printex-90 airborne concentration) at D3; the dose decreased with increasing airborne concentration (from 185 to $51 \mu \mathrm{g} / \mathrm{g}$ lung per $\mathrm{mg} / \mathrm{m}^{3}$ for 5 and $50 \mathrm{mg} / \mathrm{m}^{3}$ exposures, respectively) (Supplemental 7). Very little elimination of particles over time was recorded; a tendency to increase was even sometimes observed (perhaps due to redistribution of particles in the right median lobe?). Whatever the case, the elimination half-time was greater than 180 days.

For MWNT-7, the elimination half-time was less than 28 days, although the precision of this value is reduced due to the large number of dose measurements below the limit of quantification (Table 2).

Except for exposure to $\mathrm{P} 25$ at $1.5 \mathrm{mg} / \mathrm{m}^{3}$, a significant dose dependent influx of neutrophils was observed 
Table 2 Neutrophil influx (normalized relative to total cell count in BALF) and retained NM mass and surface area lung burden observed at various post-exposure times after 4 weeks' (or as indicated) nose-only inhalation exposure in rats

\begin{tabular}{|c|c|c|c|c|c|c|}
\hline Material & $\begin{array}{l}\text { Target concentration } \\
\left(\mathrm{mg} / \mathrm{m}^{3}\right)\end{array}$ & Post-exposure time & $\mathrm{n}=$ & $\begin{array}{l}\text { Retained amount measured } \\
\text { (mg / g lung) }\end{array}$ & $\begin{array}{l}\text { Retained surface } \\
\left(\mathrm{cm}^{2} / \mathrm{g} \text { lung }\right)\end{array}$ & Neutrophils (\%) \\
\hline \multirow[t]{6}{*}{ P25 } & 15 & $\begin{array}{l}\text { D3 } \\
\text { W4 } \\
\text { W26 }\end{array}$ & $\begin{array}{l}6 \\
6 \\
6\end{array}$ & $\begin{array}{l}3.809 \pm 0.641 \\
3.272 \pm 1.144 \\
1.328 \pm 0.873\end{array}$ & $\begin{array}{l}2095 \pm 327 \\
1800 \pm 629 \\
730 \pm 480\end{array}$ & $\begin{array}{l}40.9 \pm 7.0 \\
57.7 \pm 8.8 \\
19.9 \pm 12.7\end{array}$ \\
\hline & 15 (2-week) & D3 & 10 & $1.699 \pm 0.241$ & $935 \pm 123$ & $22.0 \pm 8.7$ \\
\hline & $5^{\mathrm{a}}$ & $\begin{array}{l}\text { D3 } \\
\text { W4 } \\
\text { W26 }\end{array}$ & $\begin{array}{l}6 \\
6 \\
6\end{array}$ & $\begin{array}{l}1.368 \pm 0.177 \\
1.386 \pm 0.384 \\
0.756 \pm 0.429\end{array}$ & $\begin{array}{l}752 \pm 90 \\
762 \pm 211 \\
416 \pm 236\end{array}$ & $\begin{array}{l}13.5 \pm 4.9 \\
12.4 \pm 7.5 \\
1.7 \pm 1.3\end{array}$ \\
\hline & $5^{\mathrm{a}}$ (2-week) & D3 & 10 & $0.672 \pm 0.127$ & $370 \pm 65$ & $5.1 \pm 4.0$ \\
\hline & $1.5^{\mathrm{a}}$ & $\begin{array}{l}\text { D3 } \\
\text { W4 } \\
\text { W26 }\end{array}$ & $\begin{array}{l}6 \\
6 \\
6\end{array}$ & $\begin{array}{l}0.511 \pm 0.125 \\
0.296 \pm 0.041 \\
0.097 \pm 0.074\end{array}$ & $\begin{array}{l}281 \pm 64 \\
163 \pm 23 \\
54 \pm 41\end{array}$ & $\begin{array}{l}2.7 \pm 2.9 \\
2.5 \pm 0.6 \\
2.2 \pm 2.6\end{array}$ \\
\hline & $1.5^{\mathrm{a}}$ (2-week) & D3 & 10 & $0.246 \pm 0.060$ & $135 \pm 31$ & $2.3 \pm 2.6$ \\
\hline P25 & $5^{b}$ & $\begin{array}{l}\text { D0 } \\
\text { D3 } \\
\text { W4 } \\
\text { W13 } \\
\text { W26 }\end{array}$ & $\begin{array}{l}6 \\
6 \\
6 \\
6 \\
6\end{array}$ & $\begin{array}{l}1.372 \pm 0.105 \\
1.286 \pm 0.152 \\
0.585 \pm 0.055 \\
0.258 \pm 0.036 \\
0.122 \pm 0.008\end{array}$ & $\begin{array}{l}700 \pm 54 \\
656 \pm 78 \\
298 \pm 28 \\
132 \pm 18 \\
62 \pm 4\end{array}$ & $\begin{array}{l}4.4 \pm 0.9 \\
8.1 \pm 2.4 \\
1.2 \pm 0.5 \\
1.0 \pm 0.6 \\
1.8 \pm 0.7\end{array}$ \\
\hline \multirow[t]{3}{*}{ Printex-90 } & 50 & $\begin{array}{l}\text { D3 } \\
\text { W4 } \\
\text { W26 }\end{array}$ & $\begin{array}{l}6 \\
6 \\
6\end{array}$ & $\begin{array}{l}2.467 \pm 0.131 \\
2.950 \pm 0.492 \\
3.708 \pm 0.631\end{array}$ & $\begin{array}{l}7797 \pm 414 \\
9322 \pm 1555 \\
11,717 \pm 1994\end{array}$ & $\begin{array}{l}72.9 \pm 5.6 \\
52.3 \pm 7.4 \\
48.3 \pm 6.4\end{array}$ \\
\hline & $15^{\mathrm{a}}$ & $\begin{array}{l}\text { D3 } \\
\text { W4 } \\
\text { W26 }\end{array}$ & $\begin{array}{l}6 \\
6 \\
6\end{array}$ & $\begin{array}{l}1.340 \pm 0.269 \\
1.418 \pm 0.234 \\
1.080 \pm 0.177\end{array}$ & $\begin{array}{l}4234 \pm 850 \\
4481 \pm 739 \\
3413 \pm 559\end{array}$ & $\begin{array}{l}55.1 \pm 19.0 \\
41.0 \pm 10.0 \\
9.5 \pm 6.0\end{array}$ \\
\hline & $5^{\mathrm{a}}$ & $\begin{array}{l}\text { D3 } \\
\text { W4 } \\
\text { W26 }\end{array}$ & $\begin{array}{l}6 \\
6 \\
6\end{array}$ & $\begin{array}{l}0.895 \pm 0.228 \\
1.428 \pm 0.372 \\
0.553 \pm 0.161\end{array}$ & $\begin{array}{l}2827 \pm 721 \\
4512 \pm 1176 \\
1747 \pm 509\end{array}$ & $\begin{array}{l}18.8 \pm 4.2 \\
5.2 \pm 1.8 \\
2.2 \pm 2.3\end{array}$ \\
\hline \multirow[t]{3}{*}{ MWNT-7 } & 1.5 & $\begin{array}{l}\text { D3 } \\
\text { W4 } \\
\text { W26 }\end{array}$ & $\begin{array}{l}6 \\
6 \\
6\end{array}$ & $\begin{array}{l}0.834 \pm 0.460 \\
0.310 \pm 0.181 \\
<0.060\end{array}$ & $\begin{array}{l}192 \pm 106 \\
71 \pm 42 \\
<14\end{array}$ & $\begin{array}{l}44.7 \pm 9.9 \\
28.3 \pm 8.9 \\
10.1 \pm 5.3\end{array}$ \\
\hline & $0.5^{\mathrm{a}}$ & $\begin{array}{l}\text { D3 } \\
\text { W4 } \\
\text { W26 }\end{array}$ & $\begin{array}{l}6 \\
6 \\
6\end{array}$ & $\begin{array}{l}0.397 \pm 0.217 \\
<0.060 \\
<0.060\end{array}$ & $\begin{array}{l}91 \pm 50 \\
<14 \\
<14\end{array}$ & $\begin{array}{l}30.6 \pm 13.5 \\
9.0 \pm 4.4 \\
8.3 \pm 8.6\end{array}$ \\
\hline & $0.15^{\mathrm{a}}$ & $\begin{array}{l}\text { D3 } \\
\text { W4 } \\
\text { W26 }\end{array}$ & $\begin{array}{l}6 \\
6 \\
6\end{array}$ & $\begin{array}{l}<0.060 \\
<0.060 \\
<0.060\end{array}$ & $\begin{array}{l}<14 \\
<14 \\
<14\end{array}$ & $\begin{array}{l}10.2 \pm 8.1 \\
4.9 \pm 6.5 \\
4.7 \pm 5.3\end{array}$ \\
\hline
\end{tabular}

${ }^{a} 6$ h-equivalent concentration created by modulating the exposure time to the aerosols

baerosol produced from a suspension by nebulization

${ }^{\mathbf{c}}$ For each experiment, control groups (exposed to filtered air) were monitored in parallel to groups of aerosol-exposed animals. In control animals, levels of \% neutrophils never exceeded $3.6 \%$ (1.8\% on average) regardless of the post-exposure time

shortly after the end of the exposure for each type of aerosol (on day 3 post-exposure). The highest neutrophil influx levels $(>40 \%)$ were observed following exposure to P25 at $15 \mathrm{mg} / \mathrm{m}^{3}$, to Printex-90 at 50 and $15 \mathrm{mg} / \mathrm{m}^{3}$, and to MWNT-7 at $1.5 \mathrm{mg} / \mathrm{m}^{3}$. The magnitude of the influx declined over time but remained above that of control animals in the majority of cases at W26 (180 days post-exposure.).

\section{Selection of studies from the literature for comparison} Table 3 presents the details of the publications identified reporting on studies involving $\mathrm{TiO}_{2}, \mathrm{MWCNT}$, and $\mathrm{CB}$ inhalation, and meeting our selection criteria. For comparison, the information from the aforementioned exposure is also included in Table 3.

The results of the various studies were analysed based on information relating to the physiochemical properties of the material (primary particle dimensions, massspecific BET surface area), the corresponding aerosol size distribution (MMAD, GSD), the rats used (sex, strain, age), the exposure details (type, duration, mass concentration) and the NM lung burden retained (NM mass per lung weight) at specified post-exposure times. Only data sets which provided all the parameters mentioned are listed in Table 3; post-exposure times for which the cytology results could not be linked to lung burden (or vice versa) or for which the lung burden 


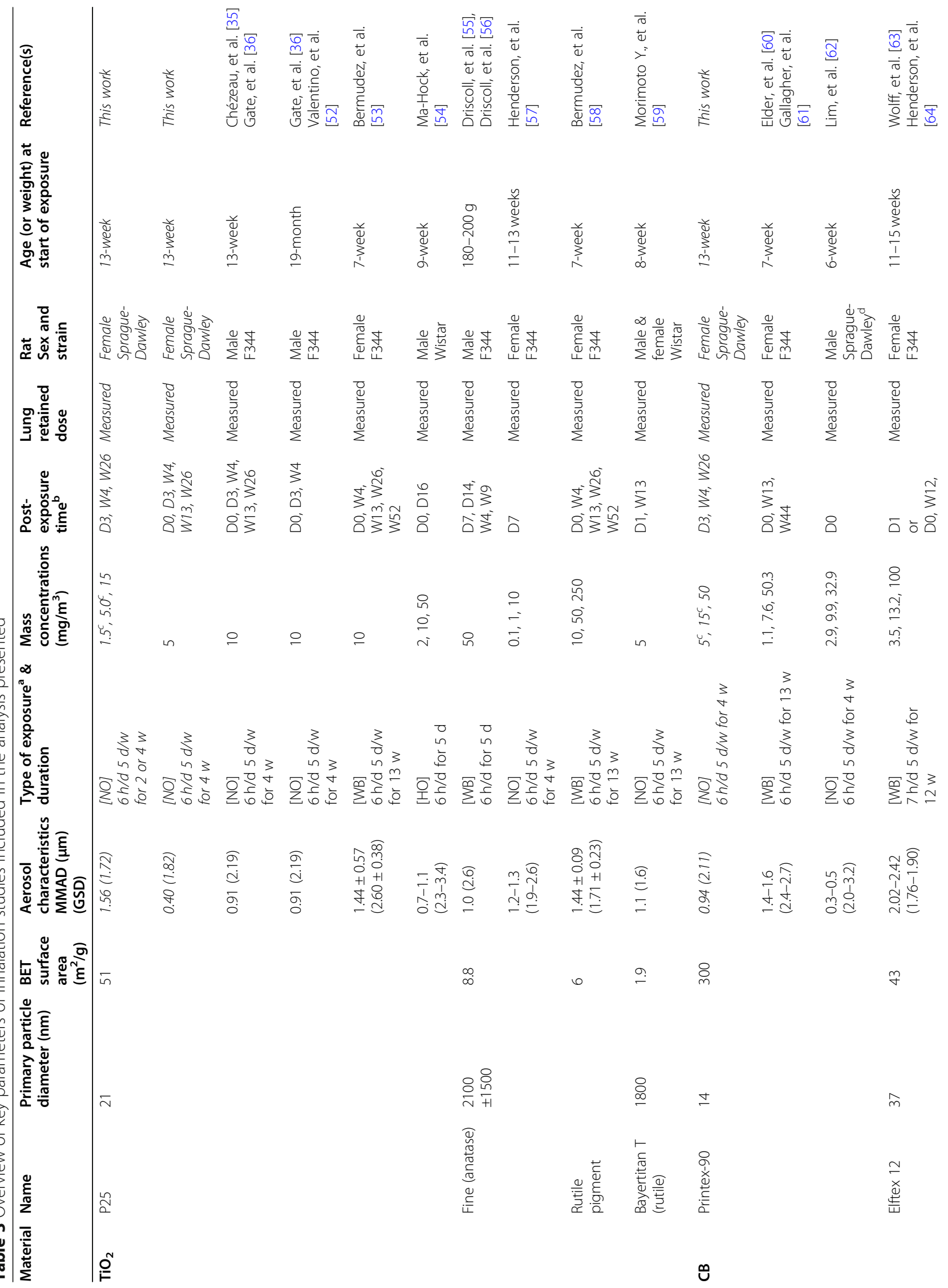




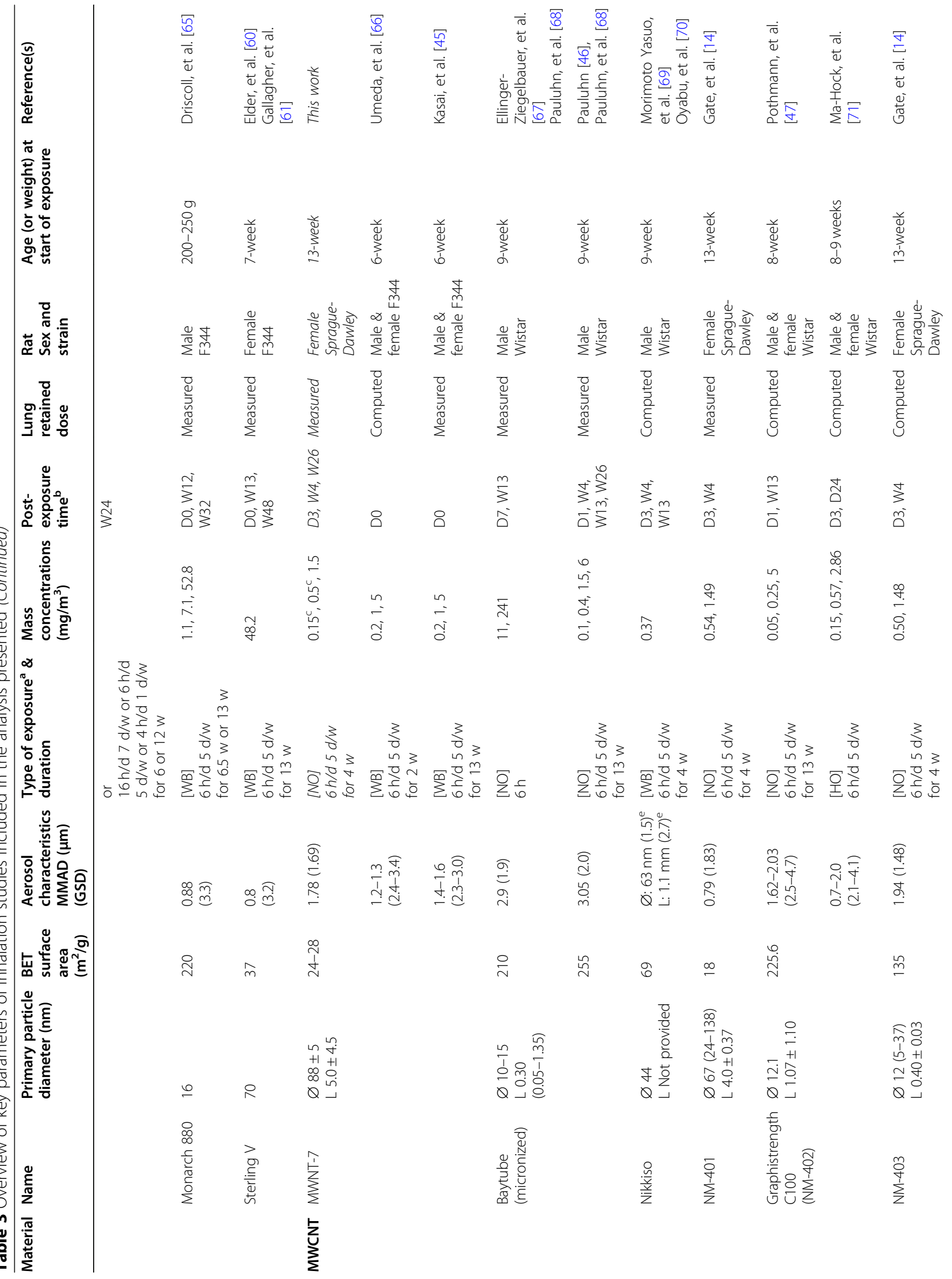




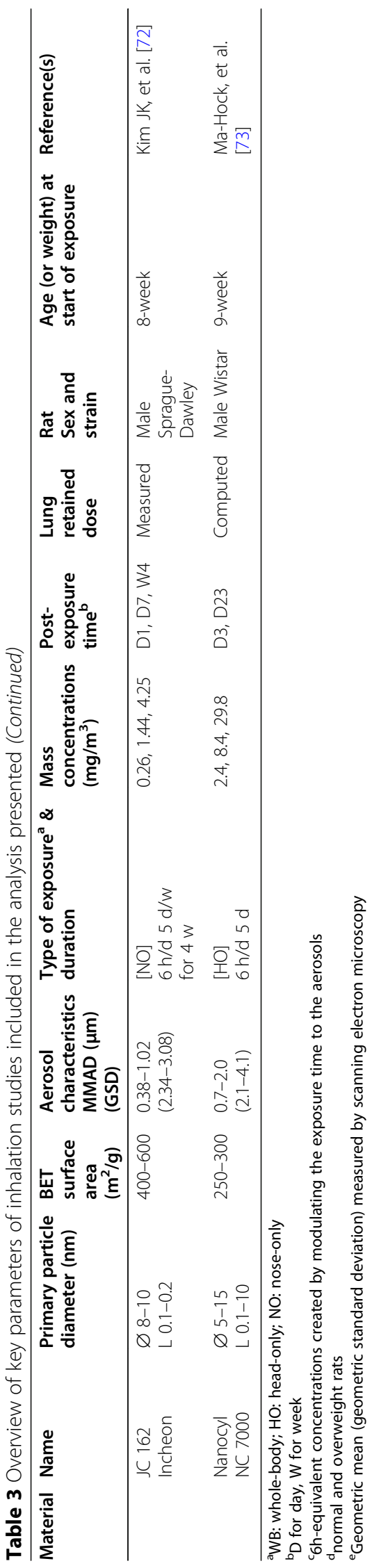


could not be estimated from the aerosol parameters using dosimetric modelling (MPPD) were not considered.

Overall, three strains of rats were used in the different studies: Fisher 344 (F344), Sprague-Dawley, and Wistar. Female or male animals were used; some studies investigated both sexes and reported no notable sex-related differences $[45,47,59,66]$. The age at the beginning of inhalation exposure generally ranged from 6 to 13 weeks, but 19-month-old (elderly) rats were used in one study [52]. There was no preferred mode of exposure (NO, HO, WB). Exposure durations varied from 1 day to 13 weeks, and post-exposure monitoring times also varied considerably, ranging from D0 (immediately following exposure) up to W52 (1 year of recovery).

Aerosol were mainly generated by dry methods, with aerosols produced from (dry) powders which were aerosolized by a combination of mechanical forces and air carriers. Several systems were used: Wright dust feeder [60, 63, 67], brush generators [54, 58], jet mill [55], Venturi jet [57, 65], acoustic generator [72], dedicated home-made dust feeder [74], etc. Sometimes, powders were milled before aerosolization [47, 67]. Only two reports described wet-based methods involving nebulization of suspensions of NMs (CB [62] or MWCNT [69]) in distilled water (possibly with Triton [56]).

For $\mathrm{TiO}_{2}$, two studies $[53,54]$ on P25 were considered along with two previous studies from our laboratory [35, 36, 52]. Except for P25, no other inhalation study on nano- $\mathrm{TiO}_{2}$ was selected as they are rare. Data for three distinct fine $\mathrm{TiO}_{2}$ (anatase and rutile) preparations were available [55-59].

Among the CB inhalation studies, only six met the selection criteria for integration into this analysis, all dealt with furnace CB. In addition to two studies on Printex90 [60-62], four others investigated Elftex 12, Monarch 88 , and Sterling V [60, 61, 63-65].

The CNT inhalation studies best met the imposed criteria, because the authors provided more experimental details. Thus, investigations of eight different CNTs meeting our selection criteria were identified. Among these studies, information was available on Baytubes [46, 67, 68], JC 162 Incheon [72], Nanocyl NC7000 [73], Nikkiso [69, 70], NM401 [14], NM402 (Graphistrength C100) [47, 71] and NM403 [14], as well as MWNT-7 $[45,66]$. These CNTs were not functionalized and differed in diameter and length.

It should be noted that the aerosol characteristics reported in studies of P25, Printex-90, or MWNT-7 tended to differ considerably. Thus, the aerosol mass concentrations reported spanned a wide range $(\geq 50$ fold) for CB (1 to $\left.50 \mathrm{mg} / \mathrm{m}^{3}\right)$ and CNT $\left(0.1\right.$ to $\left.6 \mathrm{mg} / \mathrm{m}^{3}\right)$, and 2500-fold differences were even noted for $\mathrm{TiO}_{2}$ (between 0.1 and $250 \mathrm{mg} / \mathrm{m}^{3}$ ).

\section{Relationships between neutrophil influx and retained surface area dose}

Figure 1 shows the neutrophil influx into the lung observed at various post-exposure times following 4 weeks' inhalation exposure (or on D3 following a 2-week exposure) to $\mathrm{TiO}_{2} \mathrm{P} 25$. Influx is represented as a function of the retained surface area dose normalized relative to lung weight. Further details can be found in Tables 2 and 3 . The entire dataset was well described by a sigmoid curve $\left(R^{2}=0.79\right.$; fitting parameters are provided in Table 4) with an onset dose - leading to $6 \%$ neutrophil influx (defined as $3 \times \mathrm{SD} \%$ neutro in controls) - of $430 \mathrm{~cm}^{2} / \mathrm{g}$ lung that is not influenced by post-exposure time.

Considering $\mathrm{TiO}_{2}$ exposures (P25 or other types of $\mathrm{TiO}_{2}$ (fine rutile or anatase)) with different exposure durations and post-exposure times (immediately following exposure (D0) up to a year post-exposure (W52) (Supplemental 8)), short-term exposure appeared to be more inflammogenic than longer-term exposure (Fig. 2). Indeed, distinct sigmoidal fits were obtained for curves corresponding to 1-week (acute), 4-week (+ 2 week) (subacute) and 13-week (subchronic) exposure to P25 (Table 4). Based on the 95\% confidence intervals around these three sigmoid curves, the differences were statistically significant (Fig. 3). The onset doses whatever the post-exposure time assessed - for 1-week, 4-week and 13-week exposure were 160, 430 and $2900 \mathrm{~cm}^{2} / \mathrm{g}$ lung, respectively (Table 4). This onset dose, or even better the EC50 (Table 4), was proportional to the duration of exposure (upper left corner of Fig. 3). It should be noted that all the data considered in this analysis were in fact produced by only three teams (including ours), which only considered one duration of exposure. Therefore, it cannot be excluded that part of the significant difference could have its origin in this fact. Due to the low BET surface area of fine rutile and anatase $\mathrm{TiO}_{2}$, the sigmoid curve fit reported for these particles is mainly linked to the data for 13-week exposure to rutile reported by Bermudez, et al. [58] with high aerosol mass concentrations $\left(10,50\right.$ and $250 \mathrm{mg} / \mathrm{m}^{3}$ ) (see Table 3). This curve was nevertheless statistically distinct from those obtained for 4-week and 13-week P25 exposures (see the EC50 confidence intervals on Table 4).

For Printex-90 (4-week exposure and recovery time ranging from D3 to W26) the onset dose was around $1490 \mathrm{~cm}^{2} / \mathrm{g}$ lung based on the sigmoidal curve fitted to the data reported here $\left(R^{2}=0.55\right)$ (Fig. 4, Table 4, and Supplemental 9). This curve fitting did not allow us to describe the 4-week nebulized Printex data (notable by the very weak inflammatory response induced; onset $8000 \mathrm{~cm}^{2} / \mathrm{g}$ lung) [62]. However, these data were statistically similar to the 13-week Printex-90 data [60, 61], with only a slight shift towards a higher retained dose and no effect on onset dose $\left(\sim 1300 \mathrm{~cm}^{2} / \mathrm{g}\right.$ lung, $R^{2}=$ 
-P25 (This work) = P25 from suspension (This work) — P25 (Chézeau et al. 2018) [35] ®P25 (Elderly rat) (Valentino et al. 2021) [52]

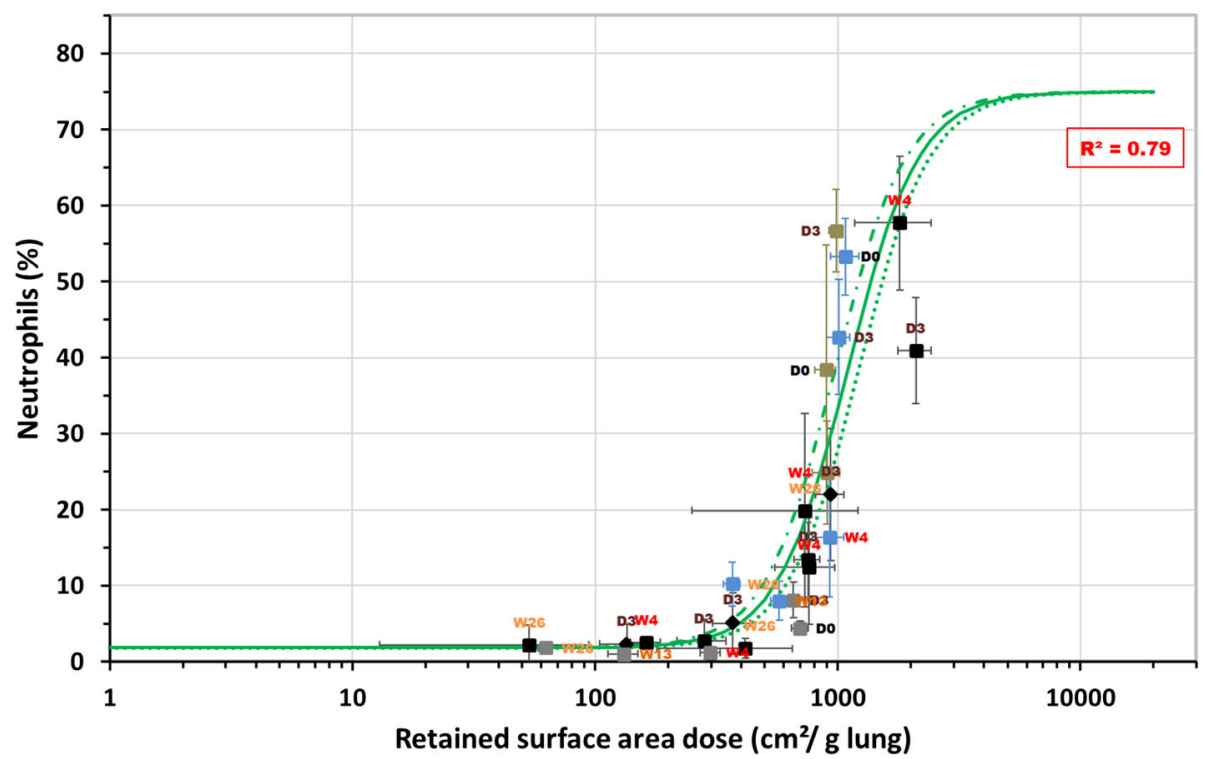

Fig. 1 Neutrophil influx observed at various post-exposure times (D0 to W26) following 4-week (square) or 2-week (diamond) inhalation exposures to $\mathrm{TiO}_{2}$ P25 depending on the measured retained surface area dose measured (see Table 3). The solid green line shows the fit of the regression model. The dotted green lines delimit the $95 \%$ confidence interval of the regression model

Table 4 Exposure conditions, curves fitting parameters and onset surface area doses leading to 6\% neutrophil infiltration for the different classes of NM studied

\begin{tabular}{|c|c|c|c|c|c|c|c|}
\hline \multirow[t]{2}{*}{ Material } & \multirow[t]{2}{*}{ Exposure } & \multirow[t]{2}{*}{ Reference } & \multirow{2}{*}{$\begin{array}{l}\text { Number of } \\
\text { conditions }^{a}\end{array}$} & \multicolumn{3}{|c|}{ Hill equation parameters ${ }^{\mathbf{b}}$} & \multirow[b]{2}{*}{$\begin{array}{l}\text { Onset } \\
\text { surface } \\
\text { area dose } \\
\left(\mathrm{cm}^{2} / \mathrm{g}\right. \\
\text { lung) } \\
\text { for } 6 \% \\
\text { neutrophils }\end{array}$} \\
\hline & & & & $\mathrm{EC50}^{\mathrm{d}}$ & Hill slope $^{d}$ & $\mathrm{R}^{2}$ & \\
\hline P25 & 2- \& 4-week & $\begin{array}{l}\text { This work } \\
+[35,36,52]\end{array}$ & 25 & $\begin{array}{l}1097 \\
{[973-1220]}\end{array}$ & $\begin{array}{l}2.98 \\
{[1.89-4.09]}\end{array}$ & 0.79 & 430 \\
\hline P25 & 13-week & [53] & 5 & $\begin{array}{l}4683 \\
{[4109-5256]}\end{array}$ & $\begin{array}{l}5.86 \\
{[0.98-10.7]}\end{array}$ & 0.91 & 2904 \\
\hline P25 & 1-week & {$[54,55]$} & 7 & $\begin{array}{l}418 \\
{[285-552]}\end{array}$ & $\begin{array}{l}2.88 \\
{[0.89-4.87]}\end{array}$ & 0.93 & 158 \\
\hline Fine $\mathrm{TiO}_{2}$ & All duration & [54-59] & 25 & $\begin{array}{l}2069 \\
{[1990-2148]}\end{array}$ & $\begin{array}{l}7.34 \\
{[5.36-9.32]}\end{array}$ & 0.99 & 1413 \\
\hline Printex-90 & 4-week & This work & 9 & $\begin{array}{l}5262 \\
{[2795-7728]}\end{array}$ & $\begin{array}{l}2.22 \\
{[-0.34-4.78]}\end{array}$ & 0.55 & 1492 \\
\hline Printex-90 & 13-week & {$[60,61]$} & 9 & $\begin{array}{l}10,038 \\
{[6348-13,728]}\end{array}$ & $\begin{array}{l}1.37 \\
{[0.50-2.24]}\end{array}$ & 0.88 & 1301 \\
\hline MWNT-7 & 2-, 4- \& 13-week & $\begin{array}{l}\text { This work } \\
+[45,66]\end{array}$ & 22 & $\begin{array}{l}61.6 \\
{[47.6-75.5]}\end{array}$ & $\begin{array}{l}1.08 \\
{[0.82-1.34]}\end{array}$ & 0.81 & 4.6 \\
\hline $\begin{array}{l}\text { + NM401, NM402, } \\
\text { NM403, Nanocyl NC7000 }\end{array}$ & All duration & $+[14,47,71,73]$ & +32 & $\begin{array}{l}90.1 \\
{[58.9-121.4]}\end{array}$ & $\begin{array}{l}0.85 \\
{[0.62-1.09]}\end{array}$ & 0.77 & 3.3 \\
\hline Micronized Baytubes & 13-week & & 16 & $\begin{array}{l}6366 \\
{[2407-10,326]}\end{array}$ & $\begin{array}{l}0.72 \\
{[0.49-0.95]}\end{array}$ & 0.87 & 130 \\
\hline
\end{tabular}

${ }^{a}$ considered for modelling; conditions means the combinaison of experimental conditions (aerosol, concentration, post-exposure time point, ...)

blow and high asymptotic \%neutrophils values are "in controls" $=1.8 \%$ and "max" $=75 \%$, respectively (see $\S$ Model fitting)

${ }^{\mathrm{c}} 6=3 \times \mathrm{SD}(\%$ neutro in controls)

${ }^{d}$ The values in brackets define the asymptotic $95 \%$ confidence intervals 


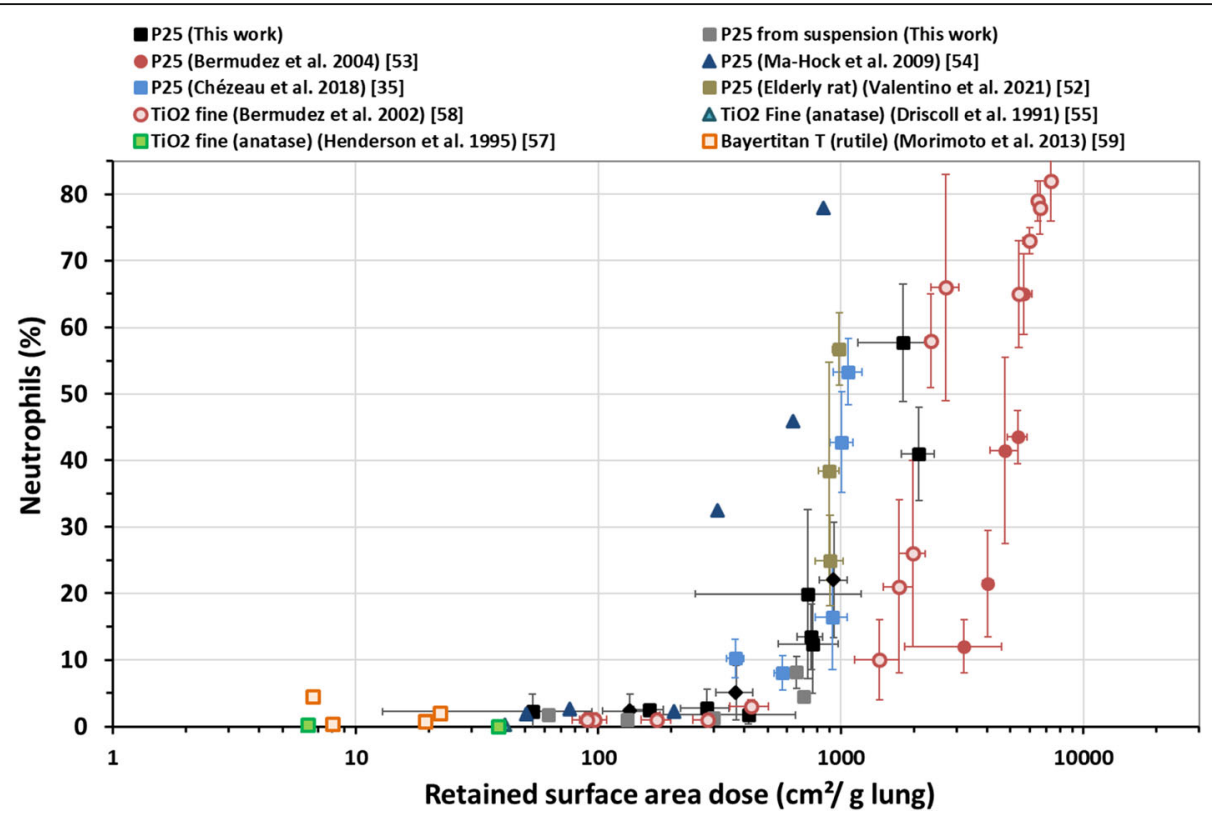

Fig. $2 \mathrm{TiO}_{2}$ material-induced effect on neutrophil influx depending on retained surface area dose measured for various exposure times: 1-week (triangle), 2-week (diamond), 4-week (square) or 13-week (circle) (see Table 3). Both nanoparticles (unicolor) and fine particles (bicolour) were considered. Details of the post-exposure times are provided in Supplemental 8

0.71) (Table 4). Unlike exposure to Sterling V [60, 61] and Monarch 880 [65], which produced dose-response curves close to those of Printex-90, the curve for Elftex $[63,64]$ was closer to the 4-week P25 curve (Fig. 4). It should be noted that the points (orange or green squares) representing the results for the 6- (or 6.5-) week exposures to Elftex-12 (or Monarch 880) tended to lie the left (i.e., lower retained surface dose) of the groups of points representing the 13-week exposures. The limited data available did not provide sufficient statistical power to conclude on an effect of exposure duration.

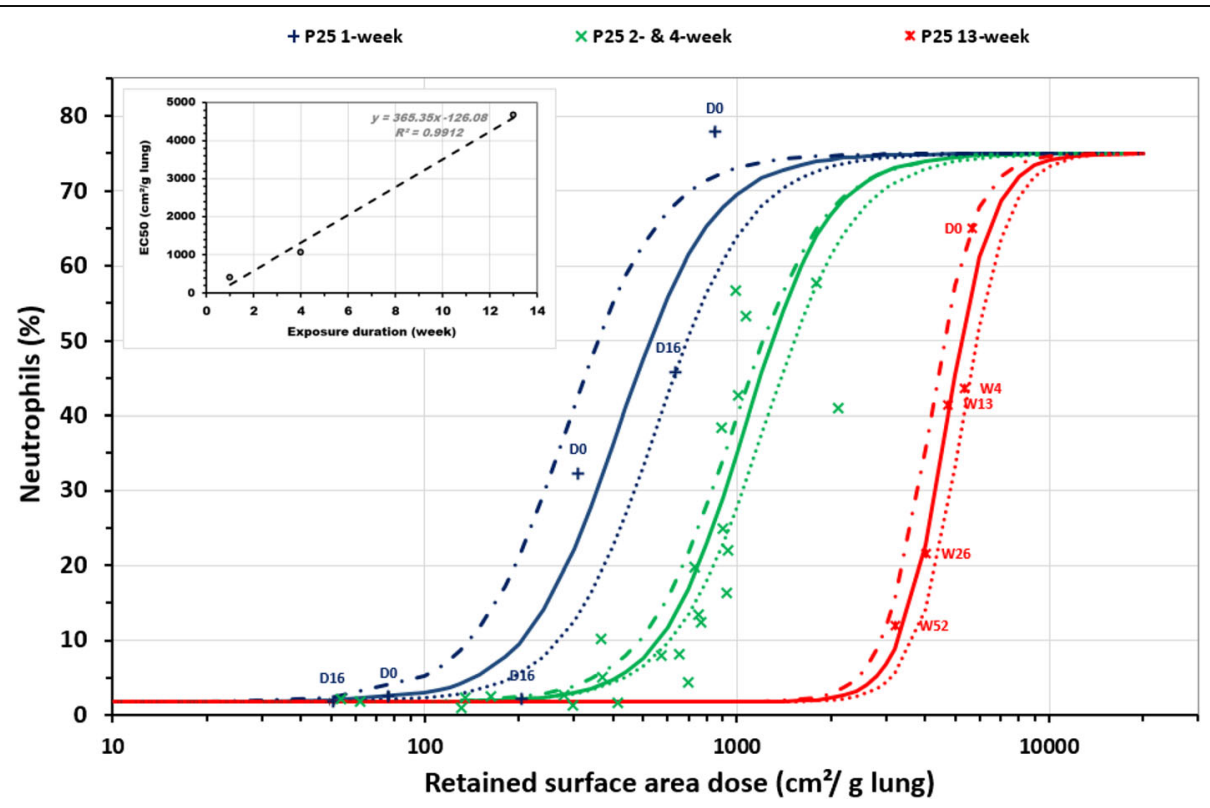

Fig. 3 Neutrophil influx depending on P25-retained surface area dose: dose rate effect. 1-week (blue +), 2- and 4-week (green X), and 13-week (red sign). The blue, green and red dotted lines represent the fit of the regression models for the 1-week, 2- and 4-week, and 13-week exposures, respectively. The dotted blue, green and red lines delimit the $95 \%$ confidence intervals of the regression models 


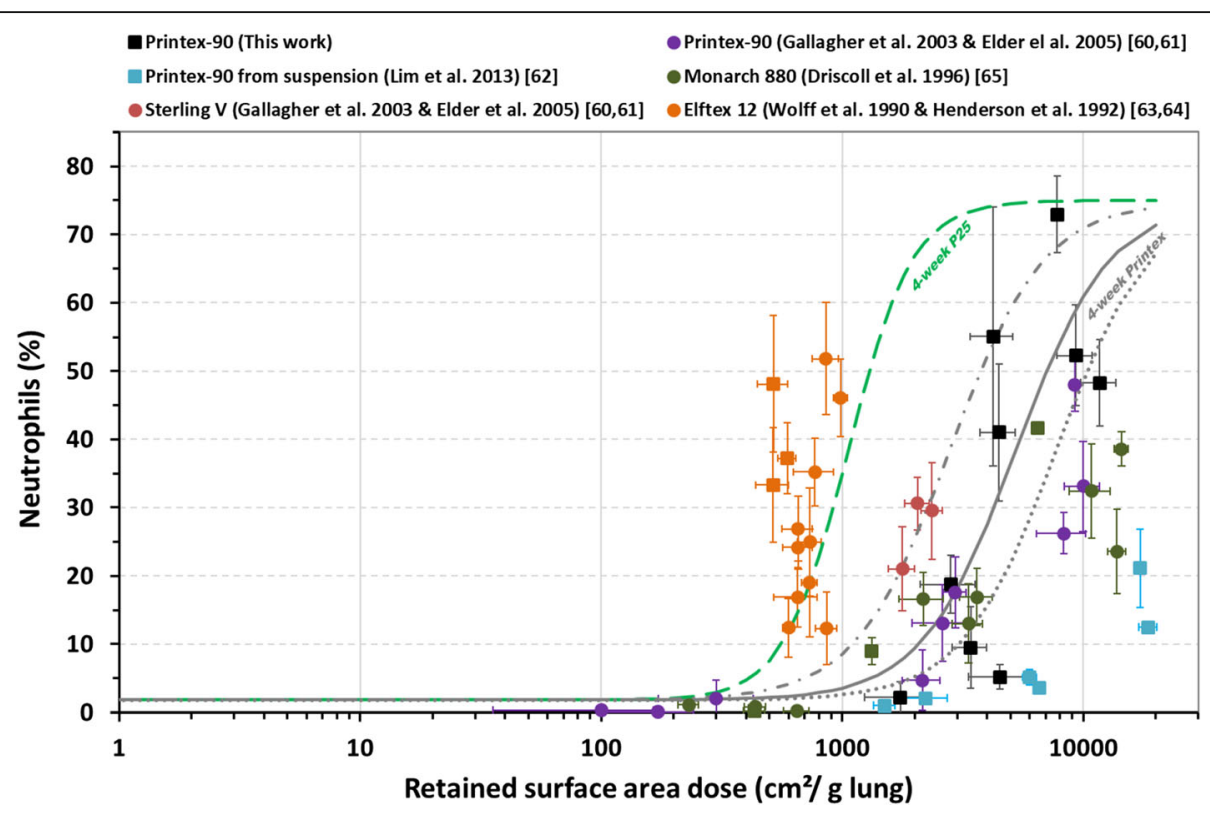

Fig. 4 CB-induced effect on neutrophil influx depending on the retained surface area dose measured following 4-week or 6-week (square) and 13-week (circle) inhalation exposure. Details of the post-exposure times are provided in Supplemental 9. The grey line shows the fit of the regression model for 4-week Printex-90 exposure (from this work). The dotted grey lines delimit the $95 \%$ confidence interval of the regression model

Regarding CNTs (Fig. 5 and Table 4), we observed a good correlation between \%neutrophils and the retained surface area dose $\left(R^{2}=0.81\right)$ for MWNT-7 data from 2-, 4- and 13-week exposures (reported here or in $[45,66])$ regardless of the post-exposure times (Supplemental 10). The MWNT-7 doseresponse relationship was very consistent with that obtained by including data from NM-401, NM-402 (Graphistrength C100), NM-403, and Nanocyl NC7000, especially if we consider that not all data were obtained with the same exposure duration $\left(R^{2}=\right.$ 0.77) $[14,47,71,73]$. For these five types of MWCN $\mathrm{T}$, the threshold concentration triggering neutrophil influx was very low ( $6 \%$ influx triggered by between 3 and $5 \mathrm{~cm}^{2} / \mathrm{g}$ lung) (Table 4). In contrast, micronized Baytubes [46, 67, 68] and JC162 [72] were much less inflammogenic. Exposure to micronized Baytubes for 13 weeks followed a dose-response curve very similar to that established for 13-week Printex-90 exposure. Nikkiso MWCNT also seemed to relate to this second "family" of CNTs, although the small number of data points available makes this conclusion difficult to affirm [69, 70].

\section{Discussion}

The aim of this study was to determine if retained surface area in the lung was a reliable metric to determine the inflammogenic potential of different classes of NM.
Inflammation is a complex process at the molecular level in an individual cell but also in the communication between different cell types. However, for the purposes of this quantitative multi-study analysis we had to select a widely used indicator of inflammation namely the "neutrophil influx" expressed by \%PMN.

It is clear that the toxicological results obtained by inhalation must be interpreted in the light of deposited (retained) doses (whether it is mass or surface) and not based on inhaled aerosol concentrations since particle deposition is significantly influenced by the characteristics of the aerosols inhaled. In addition, this internal deposited dose is essential to translate toxicological dose-response data into risk assessment and exposure limits [11].

Deposited dose expressed as mass has been the most used metric to date. This metric is generally simple to monitor and does not change over time. However, although it can be useful when studying dose-effect relationships for a specific material, it is less relevant when considering different materials, and even less so when the materials are from different families. Surface area is a more relevant dose metric, in particular for hazard grouping [12], as it can be used to identify (or demonstrate the absence of) differences in effect between distinct particles.

Shape is another important predictor. On the basis of deposited surface area, a majority of CNTs (among the non-functionalized MWCNT studied here) are more inflammogenic than $\mathrm{TiO}_{2}$, which themselves induced a 


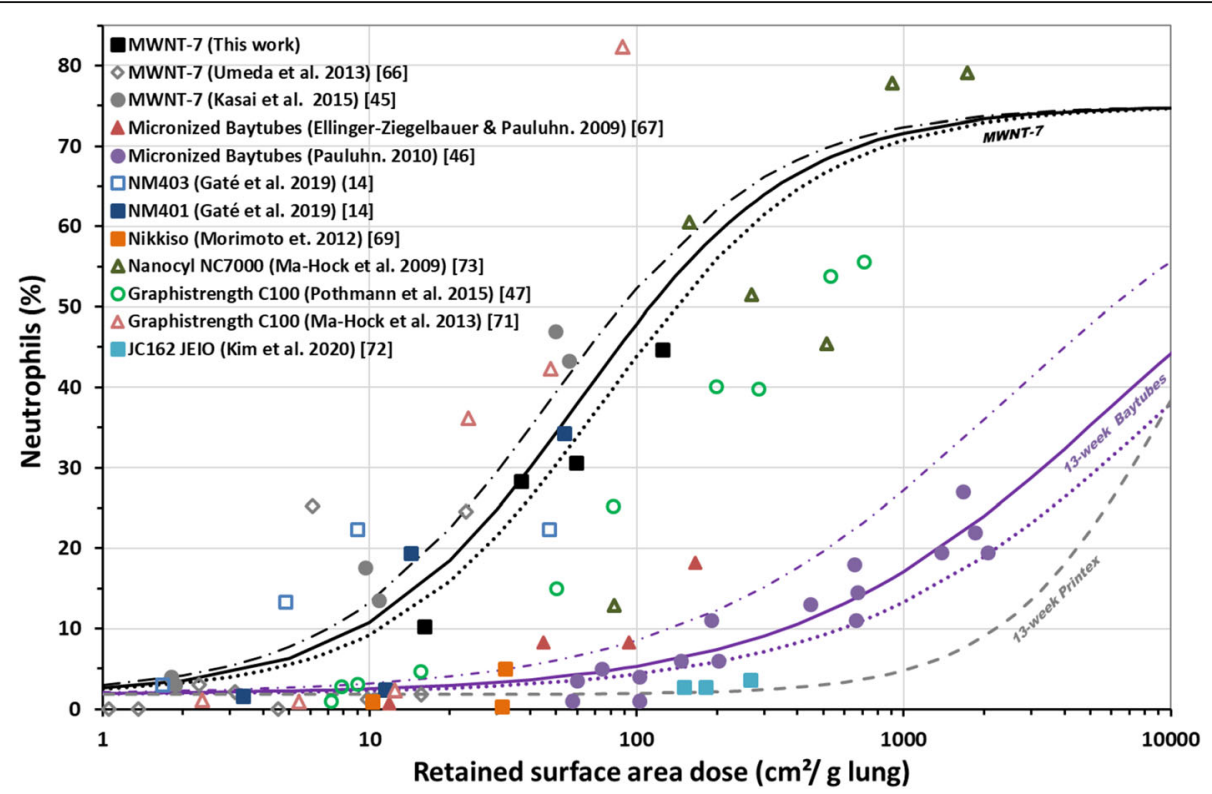

Fig. 5 MWCNT-induced effect on neutrophil influx depends on the retained surface area dose (measured or estimated) following 1-week (triangle), 2-week (diamond), 4-week (square) or 13-week (circle) inhalation exposure. Details of the post-exposure times are provided in Supplemental 10. Open symbols indicate that the retained surface area dose was estimated using the MPPD model. The retained surface "carbon" dose applied for micronized Baytubes was calculated based on Co analysis (0.53\% w/w in pristine MWCNT). The black and purples lines show the regression model fits for MWNT-7 exposure (all durations) and 13-week exposure to micronized Baytubes, respectively. The dotted black and purples lines delimit the $95 \%$ confidence intervals of the corresponding regression models

stronger inflammatory response than CBs. Indeed, we demonstrated the existence of distinct thresholds triggering an inflammatory response for the different classes of NMs. Thus, onset surface area doses estimated (for 4week exposures in Table 4) for $\mathrm{TiO}_{2}$ and CBs at 430 and $1500 \mathrm{~cm}^{2} / \mathrm{g}$ lung, respectively, were two to three orders of magnitude higher than those estimated for the more potent MWCNTs $\left(\sim 4 \mathrm{~cm}^{2} / \mathrm{g}\right.$ lung). The apparent heterogeneity in the results obtained with $\mathrm{CB}$ is difficult to explain, particularly when considering the more inflammogenic Elftex 12 [63, 64]. Possible explanations include the presence of metal impurities and highly toxic organic compounds. In addition, it appears that Printex-90 aerosol generated from an aqueous suspension displays significantly reduced surface-specific inflammogenicity [62]. This effect could be the result of water-induced passivation, as suggested by the lack of difference in surface-specific inflammogenicity after direct pulmonary application (no aerosol) of six types of $\mathrm{CB}$ suspensions with very different organic carbon content [75].

It should be noted that for PSLT, the onset surface area doses reported are at levels where lung overload conditions (reduction of lung clearance) have already been reached [76]. This marks a clear difference with the data available from inhalation with CNTs because, except for subchronic inhalation of Baytubes at 1.5 and 6 $\mathrm{mg} / \mathrm{m}^{3}$ [46], overload conditions were not reported in studies measuring MWCNT lung burden.
MWCNT could be subdivided into two groups based on the dose-response for retained surface area and inflammation. The more 'potent' group comprised NM401, NM-402 (Graphistrength), NM-403, Nanocyl NC7000, and MWNT-7. The less potent group (micronized Baytubes, JC162) behaved more like $\mathrm{TiO}_{2}$ and CB. Based only on the inflammatory response results reported here, it is impossible to determine which group Nikkiso falls into. In addition, for Nikkiso, the technique used for CNT preparation (grinding of a solidified body of MWCNT kneaded with fructose before soaking, filtration and treatment with hydrogen peroxide to remove fructose) and nebulization (from an aqueous suspension with $0.5 \mathrm{mg} / \mathrm{mL}$ Triton X-100) [69] may affect its reactivity.

Up to now, MWNT-7 is the only MWCNT classified by IARC as $2 \mathrm{~b}$ (possibly carcinogenic to humans) (our choice to use it as a benchmark material was therefore dictated by this classification more than by its physicochemical properties), other CNT are classified as 3 due to inadequate or limited evidence of carcinogenicity when the IARC assessment was performed [77]. The results presented here confirm (Fig. 5) that it does not seem to be toxicologically justified to group all carbon nanotubes into a single substance category [78], even if it could be argued from a safety point of view since there is no clear physicochemical property by which to predict group membership for a CNT. It should be noted that 
the search for the key parameter(s) driving CNT toxicity is also complicated by the fact that physicochemical properties provided by the suppliers are often imprecise or even incorrect [79]. Despite the inherent difficulties, it has been established that length is a major determinant of CNT toxicity; long MWCNT conform to the fibre paradigm, and may, like asbestos, cause frustrated phagocytosis $[8,80-82]$. The diameter and consequently the aspect ratio and rigidity of CNTs also significantly contributes to their biological effects. Thus, the rigidity of CNTs correlates strongly with both acute and chronic inflammation and frustrated phagocytosis [15, 83-85].

These considerations explain why MWNT-7, which is the best-known example of long and rigid CNTs $(\mathrm{L}=$ $5 \mu \mathrm{m}$ and $\varnothing=88 \mathrm{~nm}$ ), may cause considerable damage to the lungs following pulmonary exposure, and may explain why NM-401 $(\mathrm{L}=4 \mu \mathrm{m}$ and $\varnothing=67 \mathrm{~nm})$ or Nikkiso $(\varnothing=44 \mathrm{~nm})$ could induce a similar pathological pattern $[14,45,69,77]$.

The other CNTs investigated have smaller and more similar diameters $(\varnothing \sim 10 \mathrm{~nm})$ but ca. 50 -fold varying lengths, ranging from a few microns (5 and $1 \mu \mathrm{m}$ for Nanocyl NC7000 and Graphistrength C100, respectively) down to $0.3-0.4 \mu \mathrm{m}$ (for Baytubes and NM-403) and even $0.1-0.2 \mu \mathrm{m}$ for JC-162. In the aerosol phase, these entangled nanotubes form spherical, ovoid or elongated micronic agglomerates (in the case of JC-162, the agglomerates can even take the form of a macro tube measuring several hundreds of microns long and a few microns wide [72]). These forms limit their respirability and deposition in the alveolar region of the lung. However, our previous results from a comparative analysis of the transcriptome in the whole lung and the proteome in the BALF of rats exposed to NM-401 and NM-403 indicated that the latter (a short and/or tangled CNT usually considered less harmful) could induce pathological effects in the lung by a pathway differing from that triggered by NM-401 [86]. Indeed, following inhalation exposure to NM-401, we identified more differentially expressed genes involved in the fibrotic process than after NM-403 inhalation exposure. In addition, omics data revealed specific pathways dysregulated in NM-401 samples (e.g. cell cycle, lysosome, oxidative stress defense) in comparison to NM-403 samples (e.g. cytosolic DNA-sensing pathway, metabolic pathways).

Apart from the lower aspect ratio (around 20-25), the difference in "behaviour" between Baytubes and JC-162 on the one hand, and Nanocyl NC7000, Graphistrength C100, and NM-403 on the other, is difficult to rationalize based on simple physical parameters. Although Nanocyl NC7000 and Graphistrength C100 have aspect ratios of almost 100, that of NM-403 $(\sim 30-35)$ is just slightly higher than that of Baytubes. For the latter, authors claimed that the micronisation process (by ball milling) had no effect on the assemblage structure [46]. Nevertheless, it could be hypothesized that this treatment has sufficiently modified the surface to reduce its reactivity (to a level close to that of CBs). Investigations with other short CNTs should be performed to verify whether an aspect ratio of less than 20 can be considered a "safe" aspect ratio.

The determination of the CNT lung burden (or that of $\mathrm{CB}$, because the methodological difficulties of detecting carbon within a carbon-rich matrix such as lung tissue are similar) reported in the various studies involved a variety of methods - measurement of Co catalyst present in the CNT [67], thermal [39] or thermo-optical analysis [72], X-ray diffraction and elemental carbon analysis [70], HPLC analysis [45], light extinction [63], etc. which were not always validated according the required standards. However, it is important to point out that the uncertainties in lung burden determined cannot explain the extent of the differences observed, of one or two orders of magnitude. Likewise, the difference is such that estimates made using the MPPD model for MWNT-7, NM-403, Graphistrength C100, or Nanocyl NC7000 exposures would not lead to these NMs being classed in the other CNT subgroup.

Another important point demonstrated by the results presented here is that, when we focus on a family of $\mathrm{NMs}$, the \% neutrophils is related to the surface area dose retained within the lung regardless of the postexposure time considered. Indeed, in cases of overloading (for $\mathrm{TiO}_{2}$ and CBs) or in the presence of biopersistent NM (for some MWCNTs), the \% neutrophils remained high; in all other cases, the decrease in \% neutrophils was directly associated with the remaining surface area over time. The relation for this association takes the form of a sigmoid. In other words, the NMs are not cleared or passivated over time due to bioprocessing.

Based on surface area deposited, and at least for the inflammation phenomena considered in this article, small particles exert similar effects to larger ones, as illustrated by the inflammation results reported by Bermudez et al. [53, 58] following subchronic inhalation of fine and ultra-fine $\mathrm{TiO}_{2}$ (Fig. 2). Similarly, as clearly demonstrated here with P25 and to a lesser extent with Printex-90 and Graphistrength C100, distinct aerosols (with non-identical agglomeration states depending on the generation mode) produced from the same starting material induce equivalent inflammatory responses at the same surface area deposited dose. Only differences in lung clearance kinetics will cause the inflammation to decrease more quickly over time in one case rather than another.

There is evidence that the dose rate is a significant factor explaining differences in responses when comparing 
distinct modes of administration (instillation vs. inhalation) $[87,88]$. In general, the higher the dose rate, the smaller the surface area dose needed (for a given substance) to trigger a specific inflammatory response. In addition, this dose rate effect appears all the more important for substances with a low inflammogenic potential. For example, for NM-401 and NM-403, instillation and inhalation for 4 weeks produced the same doseresponse curve [14]. Considering only inhalation with different exposure durations, the analysis of published data alongside data produced by our laboratory revealed different onset doses following 1, 2 and 4, or 13 weeks' exposure to $\mathrm{P} 25 \mathrm{TiO}_{2}$. Based on the datasets available (and the corresponding limited statistical power) we cannot draw a definitive conclusion on the dose rate effect for $\mathrm{CB}$ (or micronized Baytubes which behave like a $\mathrm{CB})$. However, we can report trends for Printex-90, Monarch 880, and Elftex 12. The more inflammogenic MWCNT was not associated with an effect of exposure duration.

The significance/predictivity of the "retained surface area" dose for inflammogenic hazard ranking is quite striking. It nevertheless relies on many prerequisites or elements of information which are not always available in publications, demonstrated by the small number of studies suitable for inclusion in this work. The surface area calculation retained relied on lung burden measurements for inhalation, but lung burden is sometimes difficult to measure - particularly for CB and MWCNT and no standard method has yet been developed [39, 44]. Alternatively, a well-conducted characterization of the aerosol could supplement this dosage part, and we really consider that efforts in this direction are worthwhile [34]. Indeed, the deposited (or retained) surface area could be estimated from powder $\mathrm{S}_{\mathrm{BET}}$, airborne mass concentration, effective density, and regional deposited fractions using the aerosol's particle size distribution and the MPPD model (with or without the clearance module) [40-42]. It should be noted that using the BET surface area to estimate deposited surface could still be challenging with porous particles due to their high surface area. Recent studies of solid and porous $\mathrm{SiO}_{2}$ particles suggest that the internal surface area contributes to inflammation at least to some degree [19].

Regarding the MPPD model, the estimations made for MWNT-7 deposition and retention from the aerosol characterization reported by Umeda et al. [66] closely approximated the real measurements relayed by Kasai et al. [45] as well as our own data [39] (Fig. 5). Other estimations for Graphistrength C100, Nanocyl NC7000, or NM-403 appear quite efficient and relevant. It is nevertheless obvious that improvements are still needed to improve prediction. How the aspect ratio for $\mathrm{CNT}$ and fibre-like aerosols - which is of paramount importance in deposition and retention - is taken into account deserves particular attention. Likewise, the clearance module, and more specifically parameter adjustment, will also need to be improved. Studies such as the one presented here integrating an adequate (if not exhaustive) characterization of the aerosols as well as measurements taken at various post-exposure times should provide useful data for those seeking to improve existing models.

\section{Conclusion}

The results presented in this article demonstrate the correlation, in both the short-term and the long-term, between inflammation (evaluated by measuring \% PMN in BALF) and the surface area dose retained within the lung following acute to subchronic inhalation of three class of NMs: $\mathrm{TiO}_{2}, \mathrm{CBs}$ (both representing PSLT), and MWCNTs (representing HARN). The relationship between inflammation and retained surface area dose takes the form of a sigmoid curve whatever the exposure duration. The equation fitting the curve depends on the class of NM considered. Based on the surface area dose retained, most MWCNTs clearly exhibited a higher inflammatory potential than PSLT. Thus, a retained surface dose of $5 \mathrm{~cm}^{2} / \mathrm{g}$ lung was sufficient to trigger an inflammatory response with MWCNTs, whereas it was necessary to reach overload (or quasi overload) conditions with PSLT before neutrophil infiltration was measured. These conditions corresponded to retained surface area doses greater than $150 \mathrm{~cm}^{2} / \mathrm{g}$ lung.

The surface area dose is a useful metric for hazard grouping. This metric also made it possible to distinguish two categories of MWCNTs, or rather to specify the geometric limits of what is usually designated as long and thick, or short and thin tubes which would present very distinct toxicological profiles (the former being much more toxic than the latter). According to our observations, any nanotube measuring several hundred $\mathrm{nm}$ long with an aspect ratio exceeding 20-25 should be considered long and thick and potentially harmful. In addition, by using surface area as dose metric it becomes possible to account for surface-induced toxicity for both micrometric and nanometric materials.

The fact that - for a given material type and exposure scenario - \%PMN closely correlates with retained surface area dose regardless of post-exposure time has important implications for human health as it suggests that - at least for those types of materials - bioprocessing has neither a mitigating nor an aggravating effect on the surface-specific inflammogenicity of these materials in the lung. Thus, long-term pulmonary inflammation due to inhaled particles (e.g. urban dust) can be reliably predicted for humans using publicly available dosimetry models (e.g. MPPD) combined occupational and/or ambient exposure data. 
This work only considered data relating to three classes of materials; it would now deserve to be extended to include other material types and morphologies (including some porous materials).

Once sufficient data has been acquired, the inflammatory potential of a substance and its longerterm consequences could be assessed by estimating the surface area dose retained based on the BET surface area of a powder, and its aerosol parameters (rigorously determined following a well-defined aerosol characterization strategy). Using this type of approach would significantly reduce the use of animals.

\begin{abstract}
Abbreviations
AO: Adverse outcome; AOP: Adverse outcome pathway; APS: Aerodynamic particle sizer; BAL: Bronchoalveolar lavage; BALF: Bronchoalveolar fluid; BET: Brunauer-Emmett-Teller; CB: Carbon black; CFC: Closed-face cassette; CMD: Count median diameter; CMOAD: Count modal aerodynamic diameter; COPD: Chronic obstructive pulmonary disease; CPC: Condensation particle counter; D: Day; ELPI: Electrical low-pressure impactor; FRC: Functional residual capacity; HARN: High aspect ratio nanomaterial; HO: Head-only; GSD: Geometric standard deviation; KE: Key event; MMAD: Mass median aerodynamic diameter; MPPD: Multiple-Path Particle Dosimetry; MWCN T: Multiwall carbon nanotubes; NM: Nanomaterial; NO: Nose-only; OECD: Organisation for Economic Co-operation and Development; OPC: Optical particle counter; PMN: Polymorphonuclear neutrophil; PSLT: Poorly soluble particles of low toxicity; RBG: Rotating brush generator; SD: Standard deviation; SMPS: Scanning mobility particle sizer; TG: Test guideline; $\mathrm{TiO}_{2}$ : Titanium dioxide; URT: Upper respiratory tract volume; W: Week; WB: Whole-body
\end{abstract}

\section{Supplementary Information}

The online version contains supplementary material available at https://doi. org/10.1186/s12989-021-00419-w.

Additional file 1 : Supplemental 1. Inhalation set-up for P25 and Printex-90 aerosol exposures. Supplemental 2. Inhalation set-up for MWNT-7 aerosols exposure. Supplemental 3. Representative transmission electron microscopy images of (A) P25, (B) Printex-90 and (C) MWNT7 aerosols. Supplemental 4. Number (left panel) and mass (right panel) particle size distributions of (A) agglomerated P25, (B) nebulized P25, (C) Printex-90, and (D) MWNT-7 aerosols. Supplemental 5. Cytology of bronchoalveolar lavage fluid (left lung) and lung and body weights for control animals and rats exposed to the different aerosols ( $n=6$ per group). Supplemental 6. Lung burden and clearance of $\mathrm{P}_{2} 5 \mathrm{TiO}_{2}$ (normalized to the airborne $\mathrm{TiO}_{2}$ concentration and fitted with a first order kinetic model) for the different exposure conditions (RBG: dry powder; AGK: dried nebulized suspension of powder). Supplemental 7. Lung burden and clearance of Printex-90 CB (normalized to airborne CB concentration) for the different exposure conditions (dry powder). Supplemental 8. Details of the post-exposure times for $\mathrm{TiO}_{2}$ material-induced effects on neutrophil influx as a function of retained surface area dose for different exposure times as depicted in Fig. 2: 1-week (triangle), 2-week (diamond), 4-week (square) or 13-week (circle). Both nanoparticles (unicolor) and fine particles (bicolor) were considered. Supplemental 9. Details of the post-exposure times for CB-induced effects on neutrophil influx as a function of retained surface area dose for different exposure times as depicted in Fig. 4: 4-week (or 6-week for Monarch 880 and Elftex 12) (square) or 13-week (circle). Supplemental 10. Details of the postexposure times for MWCNT-induced effects on neutrophil influx as a function of retained surface area dose for different exposure times as depicted in Fig. 5: 1-week (triangle), 2-week (diamond), 4-week (square), or13-week (circle). Open symbols indicate that the retained surface area dose was estimated.

\section{Acknowledgements}

The authors gratefully acknowledge Laurine Douteau and Sylvie Michaux for their help with rat handling and husbandry, Mylène Lorcin and Sylvie Sébillaud for lung collection, Stéphane Grossmann and Stéphane Viton for aerosol generation and characterization, and Mathieu Melczer and Hervé Nunge for lung burden measurement.

Special thanks to Dr. Lan Ma-Hock from BASF (Inhalation Toxicology, ERT) for her help.

\section{Authors' contributions}

FC and LG conceptualized and designed the experiments. The inhalation setup and characterization strategy for aerosol monitoring and in-depth characterization were designed by FC and SB. FC generated and characterized aerosols, monitored animal exposure, and measured MWCNT and CB lung burden. JD contributed to developing the lung burden methods. CS, SV, and LG contributed to tissue collection and BALF analysis. FC, CS, SV, OS, UV, and LG were involved in data collection and selection of published studies. FC wrote the manuscript. All the authors discussed and agreed on the results. All the authors read, commented on, and proposed revisions to the whole manuscript. All authors approved the final manuscript.

\section{Funding}

This work was supported by the European Commission through the EU Horizon 2020 Framework Programme [Project SmartNanoTox, Grant agreement No. 686098).

\section{Availability of data and materials}

The datasets used and/or analyzed during the current study are available from the corresponding author on reasonable request.

\section{Declarations}

\section{Ethics approval and consent to participate}

Animal experiments were approved by the local Ethics Committee and registered by the French Ministry for Research and Higher Education (Authorization n00692.01 \& APAFIS\#10052).

\section{Consent for publication}

All authors have consented for publication.

\section{Competing interests}

The authors declare that they have no competing interests.

\section{Author details}

${ }^{1}$ Institut National de Recherche et de Sécurité, 1 Rue du Morvan, CS 60027, 54519 Vandœuvre-les-Nancy Cedex, France. ${ }^{2}$ Institute of Lung Biology and Disease, Helmholtz Zentrum München, 85764 Neuherberg, Germany. ${ }^{3}$ Comprehensive Pneumology Center, Munich (CPC-M) - Member of the German Center for Lung Research (DZL), 81377 Munich, Germany. ${ }^{4}$ National Research Centre for the Working Environment, Lersø Parkallé 105, DK-2100 Copenhagen, Denmark. ${ }^{5}$ Department of Health Technology by DTU Food, Technical University of Denmark, DK-2800 Kgs. Lyngby, Denmark.

Received: 3 April 2021 Accepted: 23 June 2021

Published online: 05 August 2021

\section{References}

1. Halappanavar S, van den Brule S, Nymark P, Gaté L, Seidel C, Valentino S, et al. Adverse outcome pathways as a tool for the design of testing strategies to support the safety assessment of emerging advanced materials at the nanoscale. Part Fibre Toxicol. 2020;17(1):16. https://doi.org/10.1186/ s12989-020-00344-4

2. Ede JD, Lobaskin V, Vogel U, Lynch I, Halappanavar S, Doak SH, et al. Translating scientific advances in the AOP framework to decision making for nanomaterials. Nanomaterials (Basel). 2020;10(6):1229. https://doi.org/10.33 90/nano10061229.

3. Halappanavar S, Ede JD, Shatkin JA, Krug HF. A systematic process for identifying key events for advancing the development of nanomaterial relevant adverse outcome pathways. Nanolmpact. 2019;15:100178. https:// doi.org/10.1016/j.impact.2019.100178. 
4. van Rijt SH, Bölükbas DA, Argyo C, Wipplinger K, Naureen M, Datz S, et al. Applicability of avidin protein coated mesoporous silica nanoparticles as drug carriers in the lung. Nanoscale. 2016;8(15):8058-69. https://doi.org/10.1 039/C5NR04119H.

5. Kilburn KH. Clearance mechanisms in the respiratory tract. In: Terjung R, editor. Comprehensive physiology; 2011. p. 243-62.

6. van Berlo D, Hullmann M, Schins RPF. Toxicology of ambient particulate matter. In: Luch A, editor. Molecular, clinical and environmental toxicology: volume 3: environmental toxicology. Basel: Springer Basel; 2012. p. 165-217. https://doi.org/10.1007/978-3-7643-8340-4_7.

7. Villeneuve DL, Landesmann B, Allavena P, Ashley N, Bal-Price A, Corsini E, et al. Representing the process of inflammation as key events in adverse outcome pathways. Toxicol Sci. 2018;163(2):346-52. https://doi.org/10.1093/ toxsci/kfy047.

8. Seidel C, Valentino S, Gaté L. Frustrated phagocytosis-induced lung cancer In: AOPWiki; 2020. https://aopwiki.org/aops/303. Accessed 31 May 2021.

9. Liu J, Pang Z, Wang G, Guan X, Fang K, Wang Z, et al. Advanced role of neutrophils in common respiratory diseases. J Immunol Res. 2017;6710278: 1-21. https://doi.org/10.1155/2017/6710278.

10. Henderson RF. Use of bronchoalveolar lavage to detect respiratory tract toxicity of inhaled material. Exp Toxicol Pathol. 2005:57(Suppl 1):155-9. https://doi.org/10.1016/j.etp.2005.05.004.

11. Schmid O, Cassee FR. On the pivotal role of dose for particle toxicology and risk assessment: exposure is a poor surrogate for delivered dose. Part Fibre Toxicol. 2017;14(1):52. https://doi.org/10.1186/s12989-017-0233-1.

12. Schmid $O$, Stoeger $T$. Surface area is the biologically most effective dose metric for acute nanoparticle toxicity in the lung. J Aerosol Sci. 2016;99:13343. https://doi.org/10.1016/j.jaerosci.2015.12.006.

13. Danielsen PH, Knudsen KB, Štrancar J, Umek P, Koklič T, Garvas M, et al. Effects of physicochemical properties of $\mathrm{TiO}_{2}$ nanomaterials for pulmonary inflammation, acute phase response and alveolar proteinosis in intratracheally exposed mice. Toxicol Appl Pharmacol. 2020;386:114830. https://doi.org/10.1016/j.taap.2019.114830.

14. Gate L, Knudsen KB, Seidel C, Berthing T, Chezeau L, Jacobsen NR, et al. Pulmonary toxicity of two different multi-walled carbon nanotubes in rat: comparison between intratracheal instillation and inhalation exposure. Toxicol Appl Pharmacol. 2019;375:17-31. https://doi.org/10.1016/j.taap.2019.05.001.

15. Poulsen SS, Jackson P, Kling K, Knudsen KB, Skaug V, Kyjovska ZO, et al. Multi-walled carbon nanotube physicochemical properties predict pulmonary inflammation and genotoxicity. Nanotoxicology. 2016;10(9): 1263-75. https://doi.org/10.1080/17435390.2016.1202351.

16. Nakanishi J, Morimoto Y, Ogura I, Kobayashi N, Naya M, Ema M, et al. Risk assessment of the carbon nanotube group. Risk Anal. 2015;35(10):1940-56. https://doi.org/10.1111/risa.12394.

17. Keller J, Wohlleben W, Ma-Hock L, Strauss V, Groters S, Kuttler K, et al. Time course of lung retention and toxicity of inhaled particles: short-term exposure to nano-ceria. Arch Toxicol. 2014;88(11):2033-59. https://doi.org/1 0.1007/s00204-014-1349-9.

18. Hadrup N, Saber AT, Kyjovska ZO, Jacobsen NR, Vippola M, Sarlin E, et al Pulmonary toxicity of $\mathrm{Fe}_{2} \mathrm{O}_{3}, \mathrm{ZnFe}_{2} \mathrm{O}_{4}, \mathrm{NiFe}_{2} \mathrm{O}_{4}$ and $\mathrm{NiZnFe}_{4} \mathrm{O}_{8}$ nanomaterials: inflammation and DNA strand breaks. Environ Toxicol Pharmacol. 2020;74:103303. https://doi.org/10.1016/j.etap.2019.103303.

19. Hadrup N, Aimonen K, Ilves M, Lindberg H, Atluri R, Sahlgren NM, et al. Pulmonary toxicity of synthetic amorphous silica - effects of porosity and copper oxide doping. Nanotoxicology. 2021;15(1):96-113. https://doi.org/1 0.1080/17435390.2020.1842932.

20. Hadrup N, Rahmani F, Jacobsen NR, Saber AT, Jackson P, Bengtson S, et al. Acute phase response and inflammation following pulmonary exposure to low doses of zinc oxide nanoparticles in mice. Nanotoxicology. 2019;13(9): 1275-92. https://doi.org/10.1080/17435390.2019.1654004.

21. Bendtsen KM, Gren L, Malmborg VB, Shukla PC, Tunér M, Essig YJ, et al. Particle characterization and toxicity in C57BL/6 mice following instillation of five different diesel exhaust particles designed to differ in physicochemical properties. Part Fibre Toxicol. 2020;17(1):38. https://doi. org/10.1186/s12989-020-00369-9

22. Di lanni E, Møller P, Mortensen A, Szarek J, Clausen PA, Saber AT, et al. Organomodified nanoclays induce less inflammation, acute phase response, and genotoxicity than pristine nanoclays in mice lungs. Nanotoxicology. 2020;14(7):869-92. https://doi.org/10.1080/17435390.2020.1771786.

23. Barfod KK, Bendtsen KM, Berthing T, Koivisto AJ, Poulsen SS, Segal E, et al. Increased surface area of halloysite nanotubes due to surface modification predicts lung inflammation and acute phase response after pulmonary exposure in mice. Environ Toxicol Pharmacol. 2020;73:103266. https://doi. org/10.1016/j.etap.2019.103266.

24. Warheit DB, Kreiling R, Levy LS. Relevance of the rat lung tumor response to particle overload for human risk assessment-update and interpretation of new data since ILSI 2000. Toxicology. 2016;374:42-59. https://doi.org/10.101 6/j.tox.2016.11.013

25. IARC. Some nanomaterials and some fibres. IARC Monogr Eval Carcinog Risks Hum. 2017;111:35-214.

26. IARC. Carbon black, titanium dioxide, and talc. IARC Monogr Eval Carcinog Risks Hum. 2010;93:43-276.

27. Heinrich U, Fuhst R, Rittinghausen S, Creutzenberg O, Bellmann B, Koch W, et al. Chronic inhalation exposure of Wistar rats and two different strains of mice to diesel engine exhaust, carbon black, and titanium dioxide. Inhal Toxicol. 1995:7(4):533-56. https://doi.org/10.3109/08958379509015211.

28. Kasai T, Umeda Y, Ohnishi M, Mine T, Kondo H, Takeuchi T, et al. Lung carcinogenicity of inhaled multi-walled carbon nanotube in rats. Part Fibre Toxicol. 2016;13(1):53. https://doi.org/10.1186/s12989-016-0164-2.

29. Dazon C, Witschger O, Bau S, Fierro V, Llewellyn PL. Nanomaterial identification of powders: comparing volume specific surface area, X-ray diffraction and scanning electron microscopy methods. Environ Sci Nano. 2019;6(1):152-62. https://doi.org/10.1039/C8EN00760H.

30. OECD. Guideline for the testing of chemicals: 28-day (subacute) inhalation toxicity study; 2018. p. 412.

31. OECD. Guidance document on inhalation toxicity studies: series on testing and assessment no. 39. 2018. ENV/JM/MONO(2009)28/REV1.

32. Cosnier F, Bau S, Grossmann S, Nunge H, Brochard C, Viton S, et al. Design and characterization of an inhalation system to expose rodents to nanoaerosols. Aerosol Air Qual Res. 2016;16(12):2989-3000. https://doi.org/1 0.4209/aaqr.2016.01.0034

33. McKinney W, Chen B, Frazer D. Computer controlled multi-walled carbon nanotube inhalation exposure system. Inhal Toxicol. 2009:21(12):1053-61. https://doi.org/10.1080/08958370802712713.

34. ISO. TR 13014. Nanotechnologies - Guidance on physicochemical characterization of engineered nanoscale materials for toxicologic assessment. 2012

35. Chézeau L, Sébillaud S, Safar R, Seidel C, Dembélé D, Lorcin M, et al. Shortand long-term gene expression profiles induced by inhaled $\mathrm{TiO}_{2}$ nanostructured aerosol in rat lung. Toxicol Appl Pharmacol. 2018;356:54-64. https://doi.org/10.1016/j.taap.2018.07.013.

36. Gate L, Disdier C, Cosnier F, Gagnaire F, Devoy J, Saba W, et al. Biopersistence and translocation to extrapulmonary organs of titanium dioxide nanoparticles after subacute inhalation exposure to aerosol in adult and elderly rats. Toxicol Lett. 2017;265:61-9. https://doi.org/10.1016/j.toxlet.2 016.11.009.

37. Kim HP, Kim JK, Jo MS, Park JD, Ahn K, Gulumian M, et al. Even lobar deposition of poorly soluble gold nanoparticles (AuNPs) is similar to that of soluble silver nanoparticles (AgNPs). Part Fibre Toxicol. 2020;17(1):54. https:// doi.org/10.1186/s12989-020-00384-w.

38. Devoy J, Brun E, Cosnefroy A, Disdier C, Melczer M, Antoine G, et al. Mineralization of $\mathrm{TiO}_{2}$ nanoparticles for the determination of titanium in rat tissues. J Anal Chem 2016;71(4):418-25. https://doi.org/10.1134/s1061934816040043.

39. Devoy J, Nunge H, Bonfanti E, Seidel C, Gaté L, Cosnier F. Quantitative measurement of carbon nanotubes in rat lung. Nanotoxicology. 2020;14(9): 1227-40. https://doi.org/10.1080/17435390.2020.1814439.

40. Anjilvel S, Asgharian B. A multiple-path model of particle deposition in rat lung. Fundam Appl Toxicol. 1995;28(1):41-50. https:/doi.org/10.1006/faat.1995.1144.

41. Miller FJ, Asgharian B, Schroeter JD, Price O, Corley RA, Einstein DR, et al. Respiratory tract lung geometry and dosimetry model for male SpragueDawley rats. Inhal Toxicol. 2014;26(9):524-44. https://doi.org/10.3109/089583 78.2014.925991.

42. Miller FJ, Asgharian B, Schroeter JD, Price O. Improvements and additions to the multiple path particle dosimetry model. J Aerosol Sci. 2016;99:14-26. https://doi.org/10.1016/j.jaerosci.2016.01.018.

43. Oberdorster G, Castranova V, Asgharian B, Sayre P. Inhalation exposure to carbon nanotubes (CNT) and carbon nanofibers (CNF): methodology and dosimetry. J Toxicol Env Health B Crit Rev. 2015;18(3-4):121-212. https://doi. org/10.1080/10937404.2015.1051611.

44. Wright MD, Buckley AJ, Smith R. Estimates of carbon nanotube deposition in the lung: improving quality and robustness. Inhal Toxicol. 2020;32(7):1-17. https://doi.org/10.1080/08958378.2020.1785594. 
45. Kasai T, Umeda Y, Ohnishi M, Kondo H, Takeuchi T, Aiso S, et al. Thirteenweek study of toxicity of fiber-like multi-walled carbon nanotubes with whole-body inhalation exposure in rats. Nanotoxicology. 2015;9(4):413-22. https://doi.org/10.3109/17435390.2014.933903.

46. Pauluhn J. Subchronic 13-week inhalation exposure of rats to multiwalled carbon nanotubes: toxic effects are determined by density of agglomerate structures, not fibrillar structures. Toxicol Sci. 2010;113(1):226-42. https://doi. org/10.1093/toxsci/kfp247.

47. Pothmann D, Simar S, Schuler D, Dony E, Gaering S, Le Net JL, et al. Lung inflammation and lack of genotoxicity in the comet and micronucleus assays of industrial multiwalled carbon nanotubes Graphistrength(C) C100 after a 90-day nose-only inhalation exposure of rats. Part Fibre Toxicol. 2015; 12(1):21. https://doi.org/10.1186/s12989-015-0096-2.

48. Motulsky $\mathrm{H}$, Christopoulos A. Fitting models to biological data using linear and nonlinear regression: a practical guide to curve fitting. 1st ed. U.S.A: Oxford University Press; 2004.

49. Schmid O, Karg E, Hagen DE, Whitefield PD, Ferron GA. On the effective density of non-spherical particles as derived from combined measurements of aerodynamic and mobility equivalent size. J Aerosol Sci. 2007;38(4):43143. https://doi.org/10.1016/j.jaerosci.2007.01.002.

50. Bau S, Witschger O. A modular tool for analyzing cascade impactors data to improve exposure assessment to airborne nanomaterials. J Phys Conf Ser. 2013;429:012002. https://doi.org/10.1088/1742-6596/429/1/012002.

51. Bau S, Bourrous S, Gaie-Levrel F, Witschger O. Characterization of aerosols generated from nine nanomaterial powders: reliability with regard to in vivo inhalation toxicology studies. J Nanopart Res. 2018;20(10):12. https://doi. org/10.1007/s11051-018-4381-5.

52. Valentino SA, Chézeau L, Seidel C, Sébillaud S, Lorcin M, Chalansonnet M, et al. Exposure to $\mathrm{TiO}_{2}$ nanostructured aerosol induces specific gene expression profile modifications in the lungs of young and elderly rats. Nanomaterials (Basel). 2021; 11:1466. https://doi.org/10.3390/nano11061466.

53. Bermudez E, Mangum JB, Wong BA, Asgharian B, Hext PM, Warheit DB, et al. Pulmonary responses of mice, rats, and hamsters to subchronic inhalation of ultrafine titanium dioxide particles. Toxicol Sci. 2004;77(2):347-57. https:// doi.org/10.1093/toxsci/kfh019.

54. Ma-Hock L, Burkhardt S, Strauss V, Gamer A, Wiench K, van Ravenzwaay B, et al. Development of a short-term inhalation test in the rat using nanotitanium dioxide as a model substance. Inhal Toxicol. 2009;21(2):102-18. https://doi.org/10.1080/08958370802361057

55. Driscoll K, Lindenschmidt RC, Maurer JK, Perkins L, Perkins M, Higgins J. Pulmonary response to inhaled silica or titanium dioxide. Toxicol Appl Pharmacol. 1991;111(2):201-10. https://doi.org/10.1016/0041-008x(91)900249.

56. Driscoll K, Maurer JK, Lindenschmidt RC, Romberger D, Rennard SI, Crosby L. Respiratory tract responses to dust: relationships between dust burden, lung injury, alveolar macrophage fibronectin release, and the development of pulmonary fibrosis. Toxicol Appl Pharmacol. 1990;106(1):88-101. https://doi. org/10.1016/0041-008X(90)90109-8.

57. Henderson RF, Driscoll KE, Harkema JR, Lindenschmidt RC, Chang IY, Maples $\mathrm{KR}$, et al. A comparison of the inflammatory response of the lung to inhaled versus instilled particles in F344 rats. Fundam Appl Toxicol. 1995;24(2):18397. https://doi.org/10.1006/faat.1995.1022.

58. Bermudez E, Mangum JB, Asgharian B, Wong BA, Reverdy EE, Janszen DB, et al. Long-term pulmonary responses of three laboratory rodent species to subchronic inhalation of pigmentary titanium dioxide particles. Toxicol Sci. 2002;70(1):86-97. https://doi.org/10.1093/toxsci/70.1.86.

59. Morimoto $Y$, Oyabu T, Horie M, Kambara T, Izumi H, Kuroda E, et al. Pulmonary toxicity of printer toner following inhalation and intratracheal instillation. Inhal Toxicol. 2013;25(12):679-90. https://doi.org/10.3109/08958378.2013.835010.

60. Elder A, Gelein R, Finkelstein JN, Driscoll KE, Harkema J, Oberdorster G. Effects of subchronically inhaled carbon black in three species. I. Retention kinetics, lung inflammation, and histopathology. Toxicol Sci. 2005;88(2):61429. https://doi.org/10.1093/toxsci/kfi327.

61. Gallagher J, Sams R 2nd, Inmon J, Gelein R, Elder A, Oberdorster G, et al. Formation of 8-oxo-7,8-dihydro-2'-deoxyguanosine in rat lung DNA following subchronic inhalation of carbon black. Toxicol Appl Pharmacol. 2003;190(3):224-31.

62. Lim CH, Kang M, Han JH, Yun HI. Effects of nano-sized carbon black on the lungs of high fat-diet induced overweight rats. Environ Health Toxicol. 2013; 28:e2013014. https://doi.org/10.5620/eht.2013.28.e2013014.
63. Wolff RK, Bond JA, Henderson RF, Harkema JR, Mauderly JL. Pulmonary inflammation and DNA adducts in rats inhaling diesel exhaust or carbon black. Inhal Toxicol. 1990;2(3):241-54. https://doi.org/10.3109/089583 79009145257.

64. Henderson RF, Barr EB, Cheng YS, Griffith WC, Hahn FF. The effect of exposure pattern on the accumulation of particles and the response of the lung to inhaled particles. Fundam Appl Toxicol. 1992;19(3):367-74. https:// doi.org/10.1016/0272-0590(92)90175- H.

65. Driscoll K, Carter JM, Howard BW, Hassenbein DG, Pepelko W, Baggs RB, et al. Pulmonary inflammatory, chemokine, and mutagenic responses in rats after subchronic inhalation of carbon black. Toxicol Appl Pharmacol. 1996; 136(2):372-80. https://doi.org/10.1006/taap.1996.0045.

66. Umeda Y, Kasai T, Saito M, Kondo H, Toya T, Aiso S, et al. Two-week toxicity of multi-walled carbon nanotubes by whole-body inhalation exposure in rats. J Toxicol Pathol. 2013;26(2):131-40. https://doi.org/10.1293/tox.26.131.

67. Ellinger-Ziegelbauer $\mathrm{H}$, Pauluhn J. Pulmonary toxicity of multi-walled carbon nanotubes (Baytubes) relative to alpha-quartz following a single $6 \mathrm{~h}$ inhalation exposure of rats and a 3 months post-exposure period. Toxicology. 2009;266(1-3):16-29. https://doi.org/10.1016/j.tox.2009.10.007.

68. Pauluhn J, Rosenbruch M. Lung burdens and kinetics of multi-walled carbon nanotubes (Baytubes) are highly dependent on the disaggregation of aerosolized MWCNT. Nanotoxicology. 2015;9(2):242-52. https://doi.org/1 0.3109/17435390.2014.918204.

69. Morimoto Y, Hirohashi M, Ogami A, Oyabu T, Myojo T, Todoroki M, et al. Pulmonary toxicity of well-dispersed multi-wall carbon nanotubes following inhalation and intratracheal instillation. Nanotoxicology. 2012;6(6):587-99. https://doi.org/10.3109/17435390.2011.594912.

70. Oyabu T, Myojo T, Morimoto Y, Ogami A, Hirohashi M, Yamamoto M, et al. Biopersistence of inhaled MWCNT in rat lungs in a 4-week wellcharacterized exposure. Inhal Toxicol. 2011;23(13):784-91. https://doi.org/1 0.3109/08958378.2011.608096.

71. Ma-Hock L, Strauss V, Treumann S, Kuttler K, Wohlleben W, Hofmann T, et al. Comparative inhalation toxicity of multi-wall carbon nanotubes, graphene, graphite nanoplatelets and low surface carbon black. Part Fibre Toxicol. 2013;10(1):23. https://doi.org/10.1186/1743-8977-10-23.

72. Kim JK, Jo MS, Kim Y, Kim TG, Shin JH, Kim BW, et al. 28-day inhalation toxicity study with evaluation of lung deposition and retention of tangled multi-walled carbon nanotubes. Nanotoxicology. 2020;14(2):250-62. https:// doi.org/10.1080/17435390.2019.1700568.

73. Ma-Hock L, Treumann S, Strauss V, Brill S, Luizi F, Mertler M, et al. Inhalation toxicity of multiwall carbon nanotubes in rats exposed for 3 months. Toxicol Sci. 2009;112(2):468-81. https://doi.org/10.1093/toxsci/kfp146.

74. Kasai T, Gotoh K, Nishizawa T, Sasaki T, Katagiri T, Umeda Y, et al. Development of a new multi-walled carbon nanotube (MWCNT) aerosol generation and exposure system and confirmation of suitability for conducting a single-exposure inhalation study of MWCNT in rats. Nanotoxicology. 2014;8(2):169-78. https://doi.org/10.3109/17435390.2013. 766277

75. Schmid O, Chand D, Karg E, Guyon P, Frank GP, Swietlicki E, et al. Derivation of the density and refractive index of organic matter and elemental carbon from closure between physical and chemical aerosol properties. Environ Sci Technol. 2009;43(4):1166-72. https://doi.org/10.1021/es800570p.

76. ECETOC. Poorly soluble particles / Lung overload. 2013. TR 122.

77. Kuempel ED, Jaurand M-C, Møller P, Morimoto Y, Kobayashi N, Pinkerton KE, et al. Evaluating the mechanistic evidence and key data gaps in assessing the potential carcinogenicity of carbon nanotubes and nanofibers in humans. Crit Rev Toxicol. 2017;47(1):1-58. https://doi.org/10.1080/104 08444.2016.1206061.

78. Fadeel B, Kostarelos K. Grouping all carbon nanotubes into a single substance category is scientifically unjustified. Nat Nanotechnol. 2020;15(3): 164. https://doi.org/10.1038/s41565-020-0654-0.

79. Jackson P, Kling K, Jensen KA, Clausen PA, Madsen AM, Wallin H, et al. Characterization of genotoxic response to 15 multiwalled carbon nanotubes with variable physicochemical properties including surface functionalizations in the FE1-Muta(TM) mouse lung epithelial cell line. Environ Mol Mutagen. 2015;56(2):183-203. https://doi.org/10.1002/em.21922.

80. Donaldson K, Poland CA, Murphy FA, MacFarlane M, Chernova T, Schinwald A. Pulmonary toxicity of carbon nanotubes and asbestos - similarities and differences. Adv Drug Deliv Rev. 2013;65(15):2078-86. https://doi.org/10.101 6/j.addr.2013.07.014. 
81. Donaldson K, Murphy FA, Duffin R, Poland CA. Asbestos, carbon nanotubes and the pleural mesothelium: a review of the hypothesis regarding the role of long fibre retention in the parietal pleura, inflammation and mesothelioma. Part Fibre Toxicol. 2010;7(1):5. https://doi.org/10.1186/17438977-7-5.

82. Jaurand MC, Renier A, Daubriac J. Mesothelioma: do asbestos and carbon nanotubes pose the same health risk? Part Fibre Toxicol. 2009;6(1):16. https://doi.org/10.1186/1743-8977-6-16.

83. Harik VM. Geometry of carbon nanotubes and mechanisms of phagocytosis and toxic effects. Toxicol Lett. 2017;273:69-85. https://doi.org/10.1016/j. toxlet.2017.03.016.

84. Lee D-K, Jeon S, Han Y, Kim S-H, Lee S, Yu IJ, et al. Threshold rigidity values for the asbestos-like pathogenicity of high-aspect-ratio carbon nanotubes in a mouse pleural inflammation model. ACS Nano. 2018;12(11):10867-79. https://doi.org/10.1021/acsnano.8b03604.

85. Knudsen KB, Berthing T, Jackson P, Poulsen SS, Mortensen A, Jacobsen NR, et al. Physicochemical predictors of multi-walled carbon nanotube-induced pulmonary histopathology and toxicity one year after pulmonary deposition of 11 different multi-walled carbon nanotubes in mice. Basic Clin Pharmacol Toxicol. 2019;124(2):211-27. https://doi.org/10.1111/bcpt.13119.

86. Seidel C, Zhernovkov V, Cassidy H, Kholodenko B, Matallanas D, Cosnier F, et al. Inhaled multi-walled carbon nanotubes differently modulate global gene and protein expression in rat lungs. Nanotoxicology. 2020;15(2):1-19. https://doi.org/10.1080/17435390.2020.1851418.

87. Silva RM, Doudrick K, Franzi LM, Teesy C, Anderson DS, Wu ZQ, et al. Instillation versus inhalation of multiwalled carbon nanotubes: exposurerelated health effects, clearance, and the role of particle characteristics. ACS Nano. 2014;8(9):8911-31. https://doi.org/10.1021/nn503887r.

88. Baisch BL, Corson NM, Wade-Mercer P, Gelein R, Kennell AJ, Oberdorster G, et al. Equivalent titanium dioxide nanoparticle deposition by intratracheal instillation and whole body inhalation: the effect of dose rate on acute respiratory tract inflammation. Part Fibre Toxicol. 2014;11(1):5. https://doi. org/10.1186/1743-8977-11-5.

\section{Publisher's Note}

Springer Nature remains neutral with regard to jurisdictional claims in published maps and institutional affiliations.

Ready to submit your research? Choose BMC and benefit from:

- fast, convenient online submission

- thorough peer review by experienced researchers in your field

- rapid publication on acceptance

- support for research data, including large and complex data types

- gold Open Access which fosters wider collaboration and increased citations

- maximum visibility for your research: over $100 \mathrm{M}$ website views per year

At $\mathrm{BMC}$, research is always in progress.

Learn more biomedcentral.com/submissions 